\title{
Speciation of Transition-Metal-Substituted Keggin-Type Silicotungstates Affected by the Co-crystallization Conditions with Proteinase $\mathrm{K}$
}

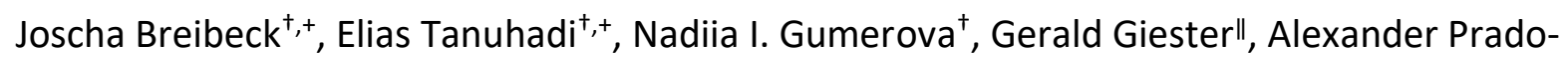
Roller $^{\ddagger}$, and Annette Rompel ${ }^{*}+$

' Universität Wien, Fakultät für Chemie, Institut für Biophysikalische Chemie, Althanstr. 14, 1090 Wien, Austria. www.bpc.univie.ac.at

॥ Universität Wien, Fakultät für Geowissenschaften, Geographie und Astronomie, Institut für Mineralogie und Kristallographie, Althanstr. 14, 1090 Wien, Austria.

₹ Universität Wien, Fakultät für Chemie, Institut für Anorganische Chemie und Zentrum für Röntgenstrukturanalyse, Währinger Str. 42, 1090 Wien, Austria.

\footnotetext{
+ These authors contributed equally to this work.

* correspondence to: annette.rompel@univie.ac.at
} 


\section{Content}

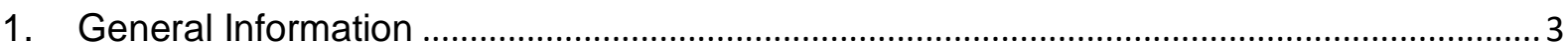

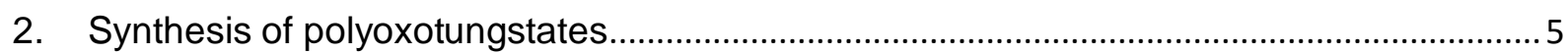

2.1. Preparation of $\mathrm{Na}_{14}\left[\left(\mathrm{~A}-\alpha-\mathrm{SiW}_{10} \mathrm{O}_{37}\right)_{2}\left\{\mathrm{CO}_{4}(\mathrm{OH})_{2}\left(\mathrm{H}_{2} \mathrm{O}\right)_{2}\right\}\right] \cdot 37 \mathrm{H}_{2} \mathrm{O} \mathrm{Na}\left\{\mathrm{SiW}_{10} \mathrm{Co}_{2}\right\}_{2} \ldots . .5$

2.2. Preparation of $\mathrm{Na}_{14}\left[\left(A-\alpha-\mathrm{SiW}_{10} \mathrm{O}_{37}\right)_{2}\left\{\mathrm{Ni}_{4}(\mathrm{OH})_{2}\left(\mathrm{H}_{2} \mathrm{O}\right)_{2}\right\}\right] \cdot 77.5 \mathrm{H}_{2} \mathrm{O} \mathrm{Na}\left\{\mathrm{SiW}_{10} \mathbf{N i}_{2}\right\}_{2} \ldots . .5$

2.3. Preparation of $\mathrm{K}_{5} \mathrm{Na}_{3}\left[A-\alpha-\mathrm{SiW}_{9} \mathrm{O}_{34}(\mathrm{OH})_{3}\left\{\mathrm{Co}_{4}(\mathrm{OAc})_{3}\right\}\right] \cdot 18 \mathrm{H}_{2} \mathrm{O}\left\{\mathrm{SiW}_{9} \mathrm{Co}_{4}\right\} \ldots \ldots \ldots \ldots \ldots . . . . .5$

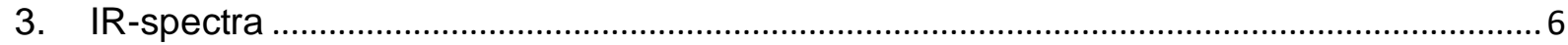

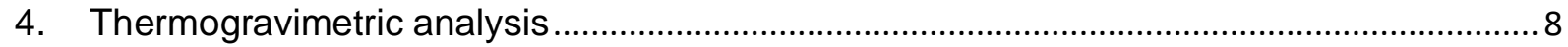

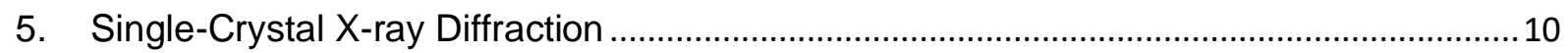

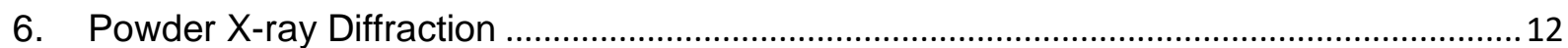

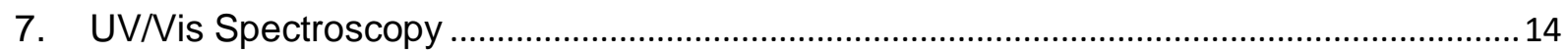

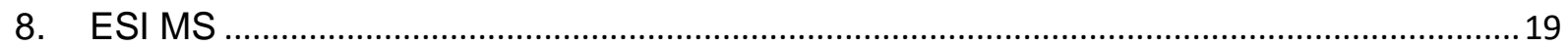

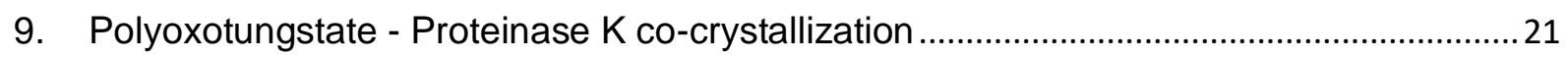

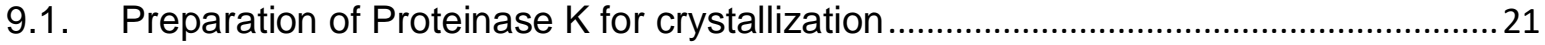

9.2. Preparation of Polyoxotungstate-Proteinase K co-crystals .......................................23

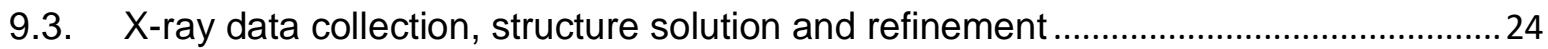

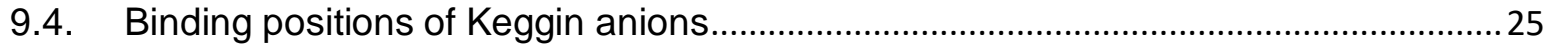

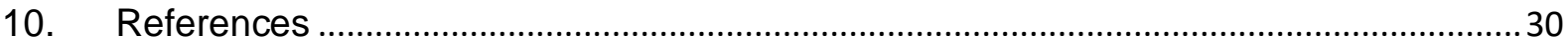




\section{General Information}

All reagents and chemicals were of high-purity grade and were used as purchased without further purification. $\mathrm{Na}_{10}\left[A-\alpha-\mathrm{SiW}_{9} \mathrm{O}_{34}\right]$ was prepared according to the literature procedure. ${ }^{1}$

Elemental analysis was carried out in aqueous solutions with $2 \% \mathrm{HNO}_{3}$ employing inductivecoupled plasma mass spectrometry (PerkinElmer Elan 6000 ICP-MS) and atomic absorption spectroscopy (PerkinElmer 1100 Flame AAS). Standards (Merck, Ultra Scientific and Analytika Prague) were prepared from $1000 \mathrm{mg} / \mathrm{L}$ single-element standard solutions.

Attenuated total reflection Fourier-transform Infrared Spectroscopy (ATR FTIR): All spectra were recorded on a Bruker Vertex70 IR Spectrometer equipped with a single-reflection diamond-ATR unit. Frequencies are given in $\mathrm{cm}^{-1}$, intensities denoted as $\mathrm{w}=$ weak, $\mathrm{m}=$ medium, $\mathrm{s}=$ strong.

Thermogravimetric analysis (TGA): TGA was performed on a Mettler SDTA851e Thermogravimetric Analyzer under $\mathrm{N}_{2}$ flow with a heating rate of $5 \mathrm{~K} \mathrm{~min}^{-1}$ in the region 298-973 K.

Single crystal $X$-ray diffraction (SXRD): The X-ray data were measured on a Nonius KappaCCD diffractometer, equipped with a $0.3 \mathrm{~mm}$ monocapillary optics collimator, graphite monochromatized MoKa-radiation, at $200 \mathrm{~K}\left(\mathrm{Na}\left\{\mathrm{SiW}_{10} \mathrm{Co}_{2}\right\}_{2}\right.$ and $\left.\mathrm{Na}\left\{\mathrm{SiW}_{10} \mathrm{Ni}_{2}\right\}_{2}\right)$ and on a Bruker D8 VENTURE equipped with a multilayer monochromator, Mo $K_{\alpha}$ Incoatec Microfocus sealed tube, and Kryoflex cooling device at $140 \mathrm{~K}\left(\left\{\mathrm{SiW}_{9} \mathrm{Co}_{4}\right\}\right)$. The structures were solved by direct methods and refined by full-matrix least-squares. Non-hydrogen atoms were refined with anisotropic displacement parameters. The following software was used for the structuresolving procedure: frame integration, Bruker SAINT software package using a narrow-frame

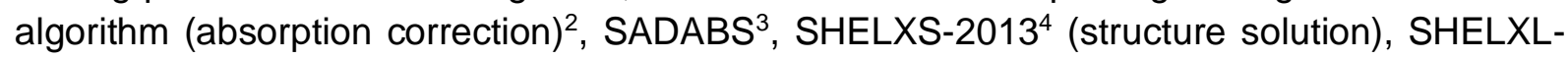
$2013^{5}$ (refinement), OLEX2 ${ }^{6}$ (structure solution, refinement, molecular diagrams, and graphical user-interface), and SHELXLE (molecular diagrams and graphical user interface). Experimental data are provided in Table S4.

Powder $X$-ray diffraction was performed on an EMPYREAN diffractometer system using CuK $K_{\alpha}$ radiation $(\lambda=1.540598)$, a PIXcel3D-Medipix3 $1 \times 1$ detector (used as a scanning line detector) and a divergence slit fixed at $0.1 \mathrm{~mm}$. The scan range was from $5^{\circ}$ to $50^{\circ}(2 \theta)$.

UV/Vis spectroscopy: UV/Vis spectra were collected on a Shimadzu UV 1800 spectrophotometer equipped with a Julaba F25 water bath to ensure a constant temperature of $20 \pm 2^{\circ} \mathrm{C}$ in the sample cuvette, mimicking the temperature of the crystallization experiments.

Electrospray ionization mass spectrometry (ESI MS): ESI MS was performed with an ESI-Qq-oaRTOF supplied by Bruker Daltonics Ltd. Bruker Daltonics Data Analysis software was used for peaks assignment. The measurement was carried out in $\mathrm{H}_{2} \mathrm{O}$ and $\mathrm{NaOAc} /$ HOAC buffer diluted with $50 \%$ of $A C N$, collected in negative and positive ion mode and with the spectrometer calibrated with the standard tune-mix to give an accuracy of ca. $5 \mathrm{ppm}$ in the region of $\mathrm{m} / \mathrm{z} 300-1900$. The signals with low intensities show an accuracy of ca. 10 ppm. 


\section{Key milestones in the application of POTs in protein crystallography}

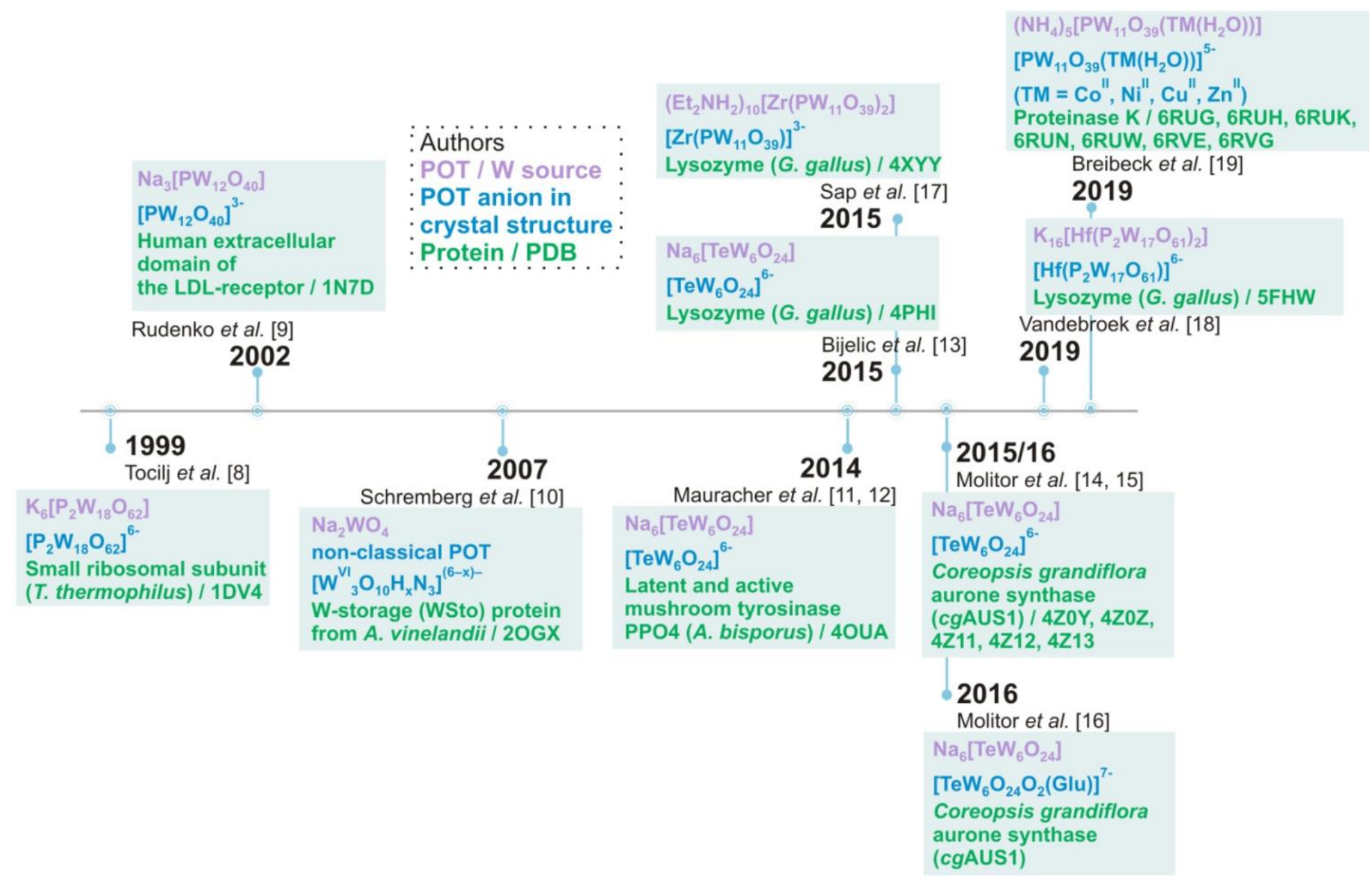

Figure S1. Key milestones in the application of POTs in protein crystallography. For the timeline, investigation, which, in the author's opinion, gave impetus to the further development of the POT's application in protein crystallography, are highlighted $[8,9,10,11,12,13,14,15,16,17,18,19]$. The names of the first authors are shown in black, the solid POT in purple, the POT anion detected in crystal structure in blue, the protein and PDB entries in green. 


\section{Synthesis of polyoxotungstates}

\subsection{Preparation of $\mathrm{Na}_{14}\left[\left(A-\alpha-\mathrm{SiW}_{10} \underline{\mathrm{O}}_{37}\right)_{2}\left\{\mathrm{CO}_{4}(\mathrm{OH})_{2}\left(\mathrm{H}_{2} \underline{\mathrm{O}}_{2}\right\}\right] \cdot 37 \mathrm{H}_{2} \mathrm{O} \mathrm{Na}\left\{\mathrm{SiW}_{10} \underline{\mathrm{Co}}_{2}\right\}_{2}\right.$}

To a vigorously stirred solution of $\mathrm{Co}(\mathrm{OAc})_{2} \cdot 4 \mathrm{H}_{2} \mathrm{O}(1.5 \mathrm{~g}, 6 \mathrm{mmol})$ in water $(75 \mathrm{ml}) \mathrm{Na}_{10}[A-$ $\alpha$-SiW $\mathrm{O}_{34}$ ] (5 g, $2 \mathrm{mmol}$ ) was added in small portions followed by stepwise heating of the reaction mixture to $80^{\circ} \mathrm{C}$. After addition of $50 \mathrm{~mL}$ of water and reaction at $80{ }^{\circ} \mathrm{C}$ for $1 \mathrm{~h}$, the reaction mixture was cooled to room temperature and passed through a cation-exchange column (AMBERLITE ${ }^{\mathrm{TM}}$ IR120 resin, Lenntech) which was equilibrated with water. Addition of a solution of $\mathrm{NaCl}(1.6 \mathrm{~g})$ in $6.25 \mathrm{~mL}$ water to the collected eluate and slow evaporation of the filtered solution at room temperature led to formation of dark red rod-shaped crystals of $\mathrm{Na}\left\{\mathrm{SiW}_{10} \mathrm{Co}_{2}\right\}_{2}$ after four weeks. Yield: $2.5 \mathrm{~g}, 20 \%$ based on W. Anal. Calcd. (\%) for $\mathrm{Na}_{14} \mathrm{H}_{80} \mathrm{Si}_{2} \mathrm{~W}_{20} \mathrm{O}_{115} \mathrm{Co}_{4}\left(\mathrm{Na}_{14}\left[\left(A-\alpha-\mathrm{SiW}_{10} \mathrm{O}_{37}\right)_{2}\left\{\mathrm{Co}_{4}(\mathrm{OH})_{2}\left(\mathrm{H}_{2} \mathrm{O}\right)_{2}\right\}\right] \cdot 37 \mathrm{H}_{2} \mathrm{O}\right): \mathrm{Na}, 5.18 ; \mathrm{Si}, 0.90$; Co, 3.80. Found: $\mathrm{Na}, 6.71$; $\mathrm{Si}, 0.87$; $\mathrm{Co}, 2.21$.

\subsection{Preparation of $\mathrm{Na}_{14}\left[\left(A-\alpha-\mathrm{SiW}_{10} \underline{\mathrm{O}}_{37}\right)_{2}\left\{\mathrm{Ni}_{4}(\mathrm{OH})_{2}\left(\mathrm{H}_{2} \mathrm{O}\right)_{2}\right\}\right] \cdot 77.5 \mathrm{H}_{2} \mathrm{O} \mathrm{Na}\left\{\mathrm{SiW}_{10} \underline{\mathrm{Ni}}_{2}\right\}_{2}$}

The synthesis of $\mathrm{Na}\left\{\mathrm{SiW}_{10} \mathrm{Ni}_{2}\right\}_{2}$ was similar to that of $\mathrm{Na}\left\{\mathrm{SiW}_{10} \mathrm{Co}_{2}\right\}_{2}$ except that a solution containing $1.5 \mathrm{~g}$ of $\mathrm{NiSO}_{4} \cdot 7 \mathrm{H}_{2} \mathrm{O}$ in $75 \mathrm{~mL} 0.5 \mathrm{M} \mathrm{NaOAc} \mathrm{pH} 6.5$ was applied as transition metal source instead of $\mathrm{Co}(\mathrm{OAc})_{2} \cdot 4 \mathrm{H}_{2} \mathrm{O}$. Yield: $2.1 \mathrm{~g}, 15 \%$ based on W. Anal. Calcd. (\%) for $\mathrm{Na}_{14} \mathrm{H}_{161} \mathrm{Si}_{2} \mathrm{~W}_{20} \mathrm{O}_{155} \mathrm{Ni}_{4}\left(\mathrm{Na}_{14}\left[\left(A-\alpha-\mathrm{SiW}_{10} \mathrm{O}_{37}\right)_{2}\left\{\mathrm{Ni}_{4}(\mathrm{OH})_{2}\left(\mathrm{H}_{2} \mathrm{O}\right)_{2}\right\}\right] \cdot 77.5 \mathrm{H}_{2} \mathrm{O}\right): \mathrm{Na}, 4.64$; $\mathrm{Si}$, $0.81 ; \mathrm{Ni}, 3.39$. Found: $\mathrm{Na}, 6.11 ; \mathrm{Si}, 0.93 ; \mathrm{Ni}, 3.75$.

\subsection{Preparation of $\mathrm{K}_{5} \mathrm{Na}_{3}\left[A-\alpha-\mathrm{SiW}_{9} \mathrm{O}_{34}(\mathrm{OH})_{3}\left\{\mathrm{CO}_{4}(\mathrm{OAc})_{3}\right\}\right] \cdot 18 \mathrm{H}_{2} \mathrm{O}\left\{\mathrm{SiW}_{9} \mathrm{CO}_{4}\right\}$}

The acetato-capped tetra-Co(II) POT $\left\{\mathrm{SiW}_{9} \mathrm{Co}_{4}\right\}$ was synthesized as described by Lisnard et al. in [20] and characterized by IR-spectroscopy (Figure S2) and SXRD (Table S4). 


\section{IR-spectra}

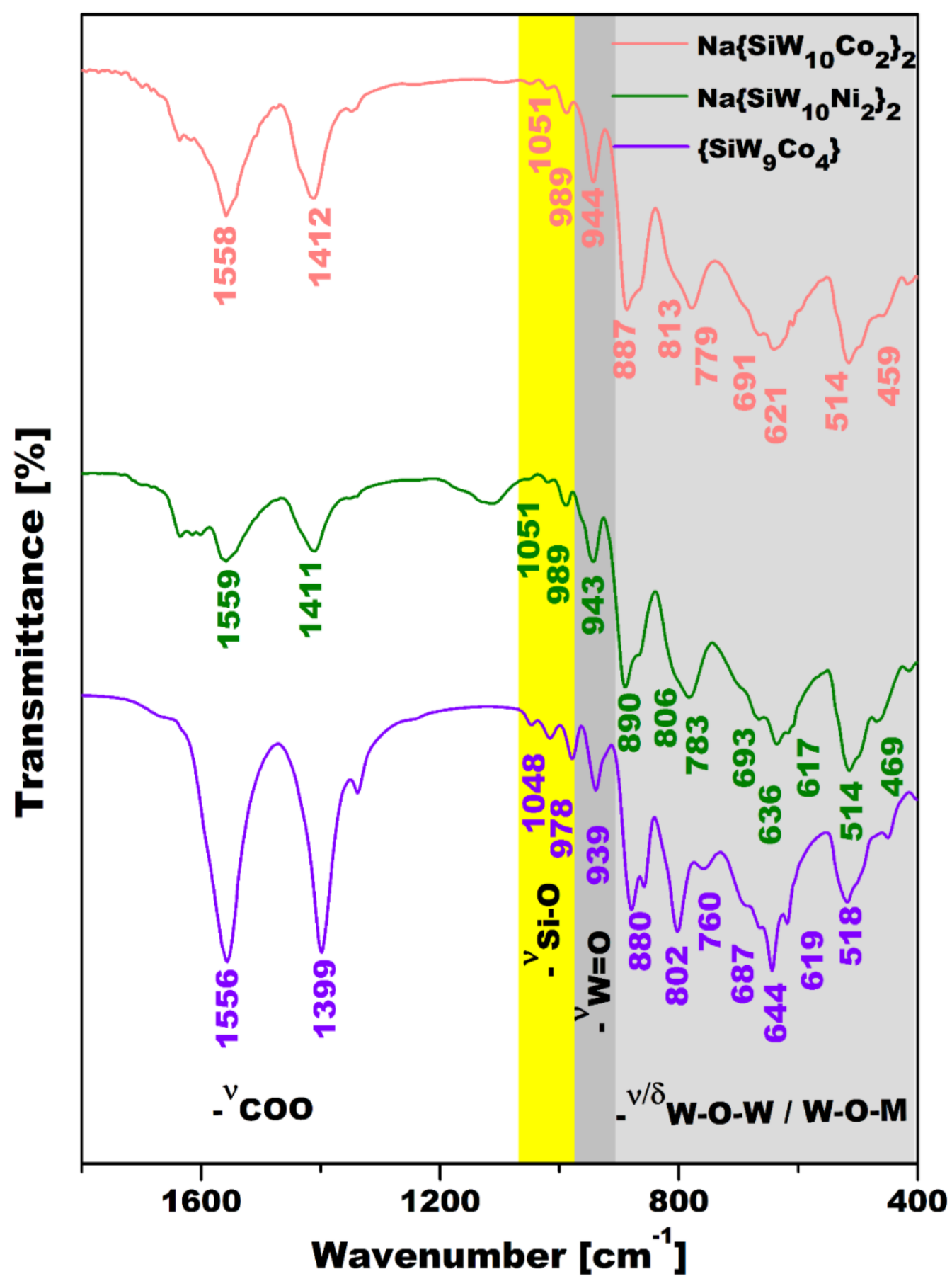

Figure S2. IR analysis of Keggin POT derivatives. The $\alpha$-Keggin Sandwich derivatives $\mathrm{Na}\left\{\mathrm{SiW}_{10} \mathrm{Co}_{2}\right\}_{2}$ and $\mathrm{Na}\left\{\mathrm{SiW}_{10} \mathrm{Ni}_{2}\right\}_{2}$ feature slight impurities of acetate salt with signals at 1558 and $1412 \mathrm{~cm}^{-1}$ (correspond to orange spectra of $\mathrm{Na}\left\{\mathrm{SiW}_{10} \mathrm{Co}_{2}\right\}_{2}$ ). These signals are strongly pronounced for the acetate-bridged POT $\left\{\mathrm{SiW}_{9} \mathrm{Co}_{4}\right\}$. As can be expected from the shared W-O core structure, the IR spectra are highly similar for all Keggin POT derivatives. ${ }^{21}$ For assignment of characteristic vibrations of the Keggin POT scaffold, see Table S1. v: vibration, $\delta$ : distortion, M: transition metal. 
Table S1. IR analysis of Keggin POT derivatives. Due to their structural similarity, the sandwich-type POT anions yielded strikingly similar signals. All samples gave rise to carboxylate vibrations from acetate, but only the acetate-capped POT showed strong signals of this ligand as part of its structure. The vibrations of COO visible in the IR spectra of $\mathrm{Na}\left\{\mathrm{SiW}_{10} \mathrm{Co}_{2}\right\}_{2}$ and $\mathrm{Na}\left\{\mathrm{SiW}_{10} \mathrm{Ni}_{2}\right\}_{2}$ indicate the presence of a small amount of simple acetate salt, which was introduced during the synthesis using $\mathrm{Co}(\mathrm{OAc})_{2}$ and $\mathrm{Ni}(\mathrm{OAc})_{2}$ as educts, respectively. $v$ : vibration, $\delta$ : distortion, M: transition metal.

\begin{tabular}{|c|c|c|c|}
\hline РОТ & Wavenumbers $\left[\mathrm{cm}^{-1}\right]$ & $\begin{array}{c}\text { Wavenumbers }\left[\mathrm{cm}^{-1}\right] \\
\text { for the literature } \\
\text { analogues } \\
\left(\left\{\mathrm{SiW} \mathrm{Co}_{4}\right\}^{20} \text { and }\right. \\
\left.\mathrm{CsNa} \mathrm{SiW}_{10} \mathrm{M}_{2^{22}}\right)\end{array}$ & Attribution \\
\hline \multirow{10}{*}{$\mathrm{Na}\left\{\mathrm{SiW}_{10} \mathrm{Co}_{2}\right\}_{2}$} & 1558,1412 & No data provided & $\checkmark \mathrm{COO}^{-}$ \\
\hline & 1051,1020 & No data provided & v Si-O \\
\hline & 989,944 & 982,939 & $v W=0$ \\
\hline & 887,865 & 895,870 & \multirow{4}{*}{$\mathrm{v}, \delta \mathrm{W}-\mathrm{O}-\mathrm{W} / \mathrm{W}-\mathrm{O}-\mathrm{Cc}$} \\
\hline & 813 & 799 & \\
\hline & 779 & & \\
\hline & 691,667 & 715,689 & \\
\hline & 641 & & \multirow{2}{*}{$v, \delta \mathrm{W}-0-\mathrm{W}$} \\
\hline & 621 & & \\
\hline & 514,459 & 530,462 & $v, \delta$ W-O-W/W-O-Co \\
\hline \multirow{10}{*}{$\mathrm{Na}\left\{\mathrm{SiW}_{10} \mathrm{Ni}_{2}\right\}_{2}$} & 1559,1411 & No data provided & $\checkmark \mathrm{COO}^{-}$ \\
\hline & 1051,1020 & No data provided & v Si-O \\
\hline & 989,943 & $987,942,938$ & $v W=0$ \\
\hline & 890,867 & 892,869 & \multirow{4}{*}{$\mathrm{v}, \delta \mathrm{W}-\mathrm{O}-\mathrm{W} / \mathrm{W}-\mathrm{O}-\mathrm{Ni}$} \\
\hline & 806 & 812 & \\
\hline & 783 & 779 & \\
\hline & 693,667 & 725,689 & \\
\hline & 636 & & \multirow{2}{*}{$v, \delta$ W-O-W } \\
\hline & 617 & & \\
\hline & 514,469 & 529,462 & $\mathrm{v}, \delta \mathrm{W}-\mathrm{O}-\mathrm{W} / \mathrm{W}-\mathrm{O}-\mathrm{Ni}$ \\
\hline \multirow{10}{*}{$\mathrm{SiW}_{9} \mathrm{Co}_{4}$} & 1556,1399 & $\begin{array}{c}1606,1556,1443 \\
1421,1348\end{array}$ & $\vee \mathrm{COO}^{-}$ \\
\hline & 1048,1016 & & v Si-O \\
\hline & 978,939 & $983,944,933$ & $v W=0$ \\
\hline & 880,859 & 889,858 & \multirow{4}{*}{$\mathrm{v}, \delta \mathrm{W}-\mathrm{O}-\mathrm{W} / \mathrm{W}-\mathrm{O}-\mathrm{Co}$} \\
\hline & 802 & 808 & \\
\hline & 760 & 742 & \\
\hline & 687,666 & 674 & \\
\hline & 644 & & \multirow{2}{*}{$v, \delta \mathrm{W}-\mathrm{O}-\mathrm{W}$} \\
\hline & 619 & & \\
\hline & 518 & 539,523 & v, ठ W-O-W/W-O-Co \\
\hline
\end{tabular}




\section{Thermogravimetric analysis}

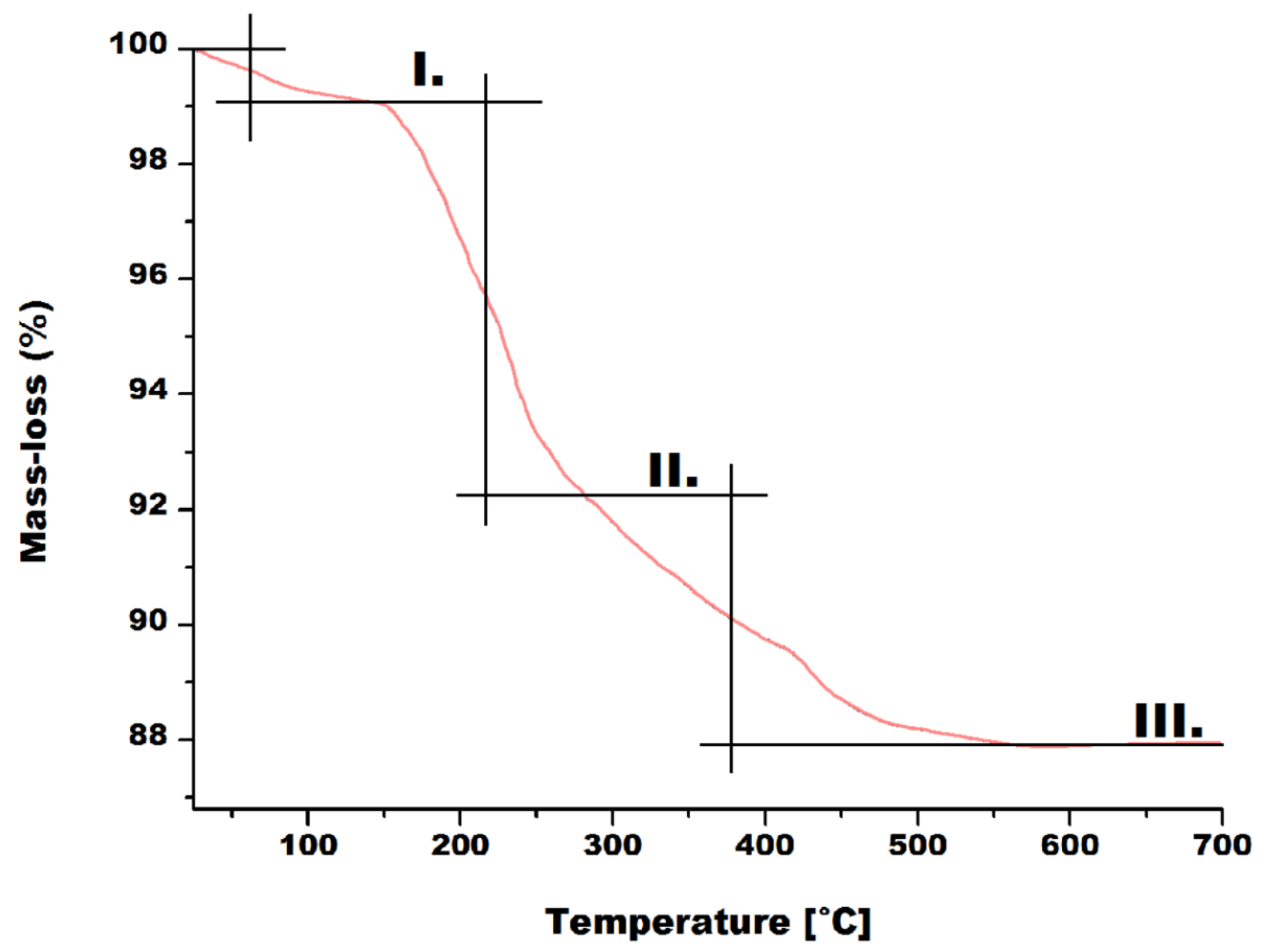

Figure S3. Thermogravimetric curve of $\mathrm{Na}_{14}\left[\left(\alpha-\mathrm{SiW}_{10} \mathrm{O}_{37}\right)_{2}\left\{\mathrm{Co}_{4}(\mathrm{OH})_{2}\left(\mathrm{H}_{2} \mathrm{O}\right)_{2}\right\}\right] \cdot 37 \mathrm{H}_{2} \mathrm{O}$ $\mathrm{Na}\left\{\mathrm{SiW}_{10} \mathrm{Co}_{2}\right\}_{2}$.

Table S2. TGA results for $\mathrm{Na}_{14}\left[\left(\alpha-\mathrm{SiW}_{10} \mathrm{O}_{37}\right)_{2}\left\{\mathrm{Co}_{4}(\mathrm{OH})_{2}\left(\mathrm{H}_{2} \mathrm{O}\right)_{2}\right\}\right] \cdot 37 \mathrm{H}_{2} \mathrm{O} \mathrm{Na}\left\{\mathrm{SiW}_{10} \mathrm{Co}_{2}\right\}_{2}$.

$\begin{array}{cccc}\text { Step } & \mathbf{T},{ }^{\circ} \mathbf{C} & \begin{array}{c}\text { mass-loss, } \\ \%\end{array} & \begin{array}{c}\text { number of } \mathbf{H}_{\mathbf{2}} \mathbf{O} \text { molecules corresponding to } \\ \text { mass-loss }\end{array} \\ \text { I } & 25-150 & 1.04 & 3 \\ \text { II } & 150-300 & 6.64 & 22 \\ \text { III } & 300-700 & 4.16 & 14\end{array}$




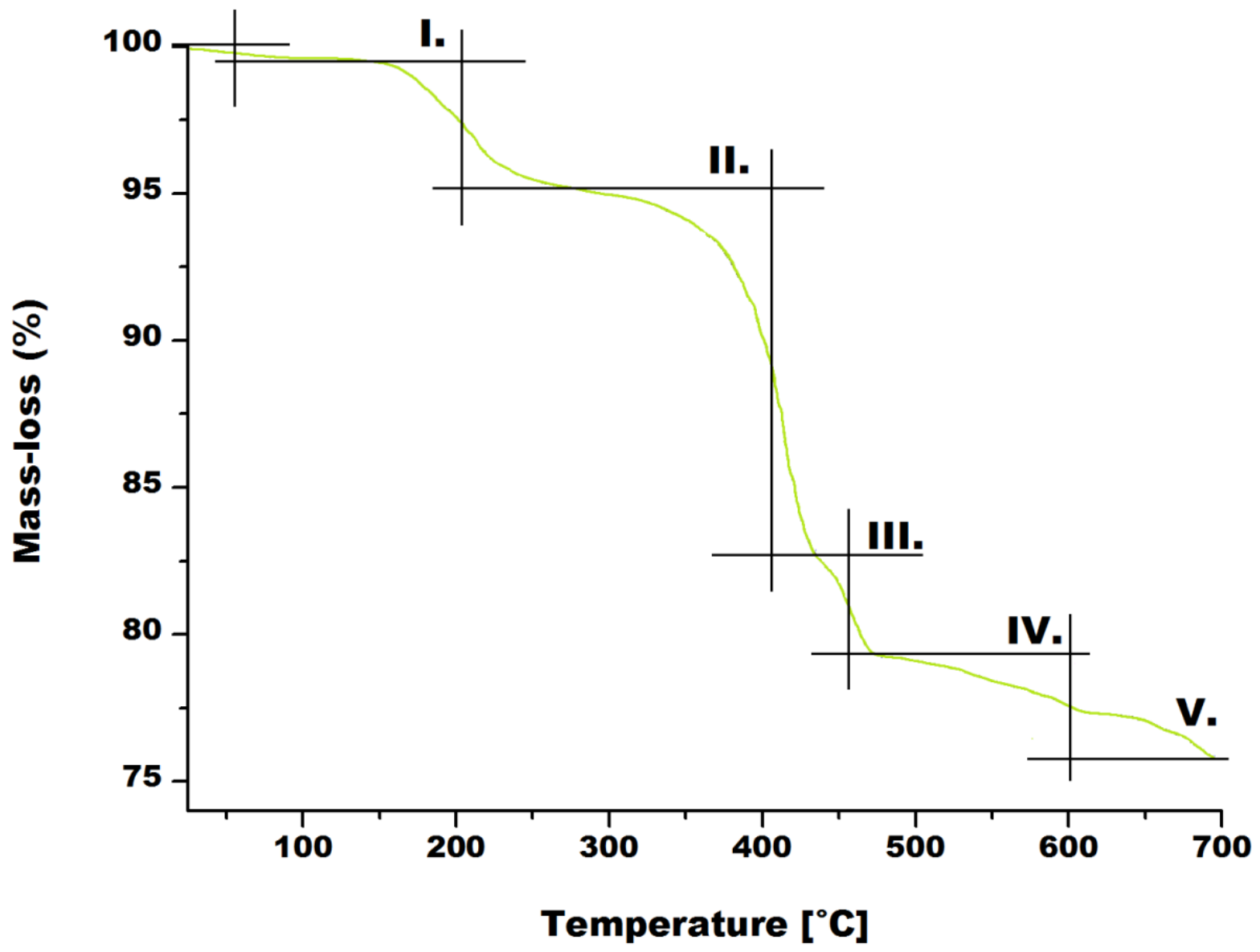

Figure S4. Thermogravimetric curve of $\mathrm{Na}_{14}\left[\left(\alpha-\mathrm{SiW}_{10} \mathrm{O}_{37}\right)_{2}\left\{\mathrm{Ni}_{4}(\mathrm{OH})_{2}\left(\mathrm{H}_{2} \mathrm{O}\right)_{2}\right\}\right] \cdot 77.5 \mathrm{H}_{2} \mathrm{O}$ $\mathrm{Na}\left\{\mathrm{SiW}_{10} \mathrm{Ni}_{2}\right\}_{2}$.

Table S3. TGA results for $\mathrm{Na}_{14}\left[\left(\alpha-\mathrm{SiW}_{10} \mathrm{O}_{37}\right)_{2}\left\{\mathrm{Ni}_{4}(\mathrm{OH})_{2}\left(\mathrm{H}_{2} \mathrm{O}\right)_{2}\right\}\right] \cdot 77.5 \mathrm{H}_{2} \mathrm{O} \mathrm{Na}\left\{\mathrm{SiW}_{10} \mathrm{Ni}_{2}\right\}_{2}$.

$\begin{array}{cccc}\text { Step } & \mathbf{T},{ }^{\circ} \mathbf{C} & \begin{array}{c}\text { mass-loss, } \\ \%\end{array} & \begin{array}{c}\text { number of } \mathbf{H}_{\mathbf{2}} \mathbf{O} \text { molecules corresponding to } \\ \text { mass-loss }\end{array} \\ \text { I } & 25-150 & 0.49 & 1.5 \\ \text { II } & 150-250 & 4.25 & 14 \\ \text { III } & 250-430 & 12.13 & 42.5 \\ \text { IV } & 430-470 & 3.32 & 10.5 \\ \text { V } & 470-700 & 3.46 & 11\end{array}$




\section{Single-Crystal X-ray Diffraction}

Table S4. X-ray characteristics of Keggin POT derivatives. The full single-crystal X-ray analysis confirmed the successful re-synthesis of $\left\{\mathrm{SiW}_{9} \mathrm{Co}_{4}\right\}$; published cell parameters ${ }^{20}$ and temperature are given in brackets for comparison.

\begin{tabular}{|c|c|c|c|}
\hline abbreviation & $\left\{\mathrm{SiW}_{9} \mathrm{Co}_{4}\right\}$ & $\mathrm{Na}\left\{\mathrm{SiW}_{10} \mathrm{Co}_{2}\right\}_{2}$ & $\mathrm{Na}\left\{\mathrm{SiW}_{10} \mathrm{Ni}_{2}\right\}_{2}$ \\
\hline Sum formula & $\mathrm{C}_{6} \mathrm{H}_{48} \mathrm{Co}_{4} \mathrm{~K}_{5} \mathrm{Na}_{3} \mathrm{O}_{61} \mathrm{SiW}_{9}$ & $\mathrm{Na}_{14} \mathrm{H}_{80} \mathrm{Si}_{2} \mathrm{~W}_{20} \mathrm{O}_{115} \mathrm{Co}_{4}$ & $\mathrm{Na}_{14} \mathrm{H}_{161} \mathrm{Si}_{2} \mathrm{~W}_{20} \mathrm{O}_{155} \mathrm{Ni}_{4}$ \\
\hline$M_{t}$ & 3279.3 & 6211.1 & 6931.8 \\
\hline $\mathbf{T}[\mathrm{K}]$ & $140(293)$ & 200 & 200 \\
\hline Crystal system & monoclinic & triclinic & triclinic \\
\hline Space group & $P 2_{1} / m$ & $P 1$ & $P 1$ \\
\hline 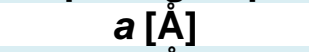 & $10.7619(10.7959)$ & $11.4253(19)$ & $11.4457(10)$ \\
\hline$b[\AA]$ & $14.9262(14.803)$ & 13.697(2) & $13.7694(12)$ \\
\hline$c[\AA]$ & 19.141 (19.137) & 19.094(3) & $19.3056(18)$ \\
\hline$\alpha\left[^{\circ}\right]$ & $90(90)$ & $89.386(4)$ & $90.966(2)$ \\
\hline$\beta\left[^{\circ}\right]$ & 93.668 (93.407) & $105.382(4)$ & $106.049(2)$ \\
\hline$Y\left[^{\circ}\right]$ & $90(90)$ & $113.621(4)$ & $112.919(2)$ \\
\hline$V\left[\AA^{3}\right]$ & 3069 (3053) & 2624.1(7) & $2666.4(4)$ \\
\hline$Z$ & $2(3)$ & 1 & 1 \\
\hline$\rho_{\text {calc }}\left[\mathrm{g} \mathrm{cm}^{-3}\right]$ & - & 3.863 & 3.891 \\
\hline$\mu\left[\mathbf{m m}^{-1}\right]$ & - & 22.620 & 22.356 \\
\hline data/parameters & - & $9498 / 700$ & 20293/746 \\
\hline $\boldsymbol{R}_{\text {int }}$ & - & 0.0699 & 0.0759 \\
\hline goodness of fit & - & 1.048 & 1.115 \\
\hline$R[\mathrm{I}>2 \sigma(\mathrm{I})]$ & - & $\begin{array}{c}R_{1}=0.1125 \\
w R_{2}=0.2860\end{array}$ & $\begin{array}{c}R_{1}=0.0458 \\
w R_{2}=0.1139\end{array}$ \\
\hline
\end{tabular}

Table S5. Selected bond valence sum (BVS) values for $\mathrm{Na}\left\{\mathrm{SiW}_{10} \mathrm{Co}_{2}\right\}_{2}$ and $\mathrm{Na}\left\{\mathrm{SiW}_{10} \mathrm{Ni}_{2}\right\}_{2}$.

\begin{tabular}{|c|c|c|c|}
\hline РОТ & Atom sort & Atom center & BVS value \\
\hline \multirow{7}{*}{$\mathrm{Na}\left\{\mathrm{SiW}_{10} \mathrm{Co}_{2}\right\}_{2}$} & $\mu_{2}-$ oxo & $\mathrm{O} 28$ & $-2,01$ \\
\hline & $\mu_{2}-\mathrm{oxo}$ & O29 & $-1,87$ \\
\hline & $\mu_{2}-\mathrm{oxo}$ & O5 & $-1,80$ \\
\hline & $\mu_{2}-0 \times 0$ & O37 & $-1,77$ \\
\hline & $\mu_{2}-\mathrm{oxo}$ & 015 & $-1,74$ \\
\hline & $\mu_{2}-$ oxo & $\mathrm{O} 34$ & $-1,73$ \\
\hline & $\mu_{3}-$ hydroxo & O39 & $-0,76$ \\
\hline \multirow{7}{*}{$\mathrm{Na}\left\{\mathrm{SiW}_{10} \mathrm{Ni}_{2}\right\}_{2}$} & $\mu_{2}-\mathrm{oxO}$ & O29 & $-1,88$ \\
\hline & $\mu_{2}-$ oxo & O34 & $-1,83$ \\
\hline & $\mu_{2}-\mathrm{oxO}$ & O37 & $-1,82$ \\
\hline & $\mu_{2}-\mathrm{oxo}$ & O5 & $-1,81$ \\
\hline & $\mu_{2}-\mathrm{oxo}$ & $\mathrm{O} 28$ & $-1,80$ \\
\hline & $\mu_{2}-\mathrm{oxo}$ & 015 & $-1,75$ \\
\hline & $\mu_{3}-$ hydroxo & O39 & $-0,74$ \\
\hline
\end{tabular}


The architecture of the isostructural $\mathbf{N a}\left\{\mathrm{SiW}_{10} \mathrm{Ni}_{2}\right\}_{2}$ and $\mathrm{Na}\left\{\mathrm{SiW}_{10} \mathrm{Co}_{2}\right\}_{2}$ represents a dimer of $\left[\alpha-\mathrm{SiW}_{10} \mathrm{O}_{37}\right]^{10-}$ ions (Figure S5 A, B). The overall atom connectivity in $\mathbf{N a}\left\{\mathrm{SiW}_{10} \mathbf{M}_{2}\right\}_{2}$ features a central square-shaped motif of two $\mathrm{M}^{\prime \prime}$ centers and two $\mu_{3}-\mathrm{OH}$. Thereby, all four $\mathrm{M}^{\prime \prime}$ atoms are linked through only two $\mu_{3}$-oxygens. Since the half-units are related by an inversion center, there are only two structurally non-equivalent types of $M^{\prime \prime}$ centers exhibiting a distorted octahedral coordination environment with $\mathrm{M}-\mathrm{O}$ distances ranging from 2.001(6) to 2.27(3) $\AA$, which is in accordance with the findings reported by Haider et al. ${ }^{22}$ In $\mathrm{Na}\left\{\mathrm{SiW}_{10} \mathrm{M}_{2}\right\}_{2}$, each $\alpha$-SiW ${ }_{10} \mathrm{O}_{37}$ unit bears one labile water ligand and a very reactive $\mu_{3}-\mathrm{OH}$ site, as well as six basic $\mu_{2}-\mathrm{O}$ positions bridging $\mathrm{W}^{\mathrm{Vl}}$ and $\mathrm{Co}^{\prime \prime}$ or Nill. These oxo-sites show a pronounced protonation propensity as indicated by bond valence sum calculations (BVS) (Table S5).
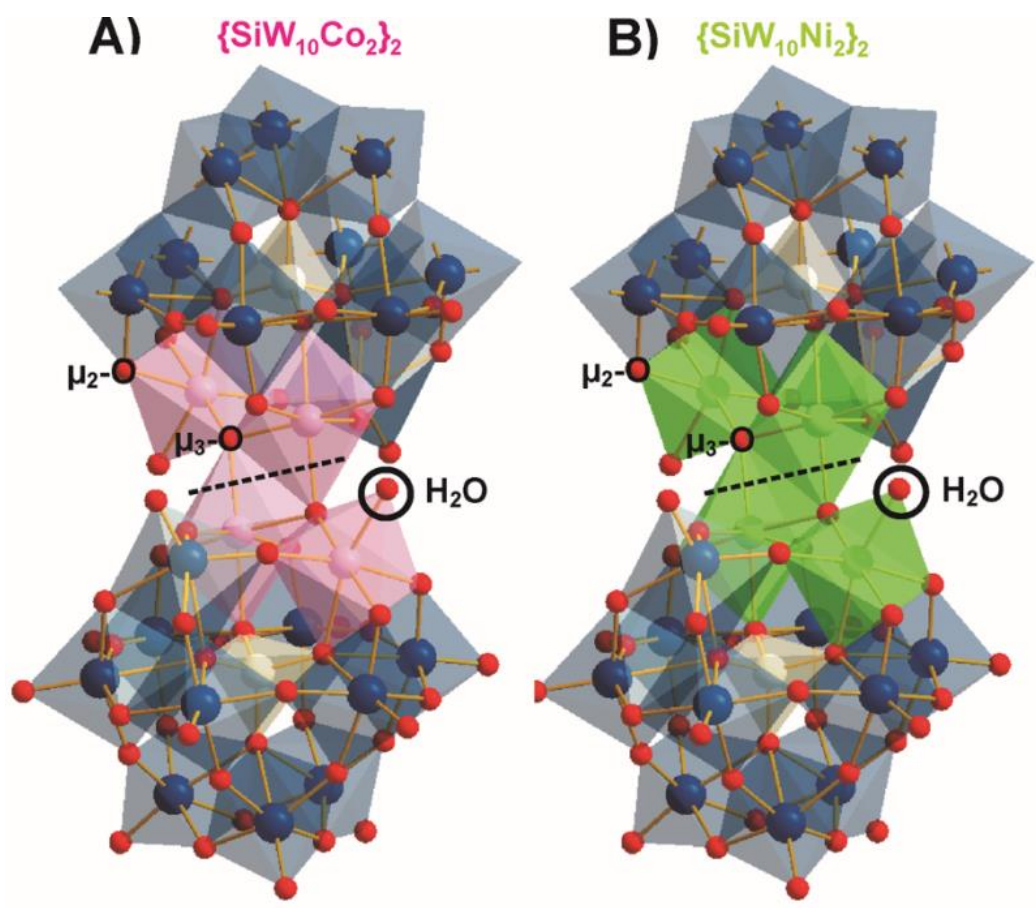

\section{C) $\left\{\mathrm{SiW}_{9} \mathrm{Co}_{4}\right\}$}

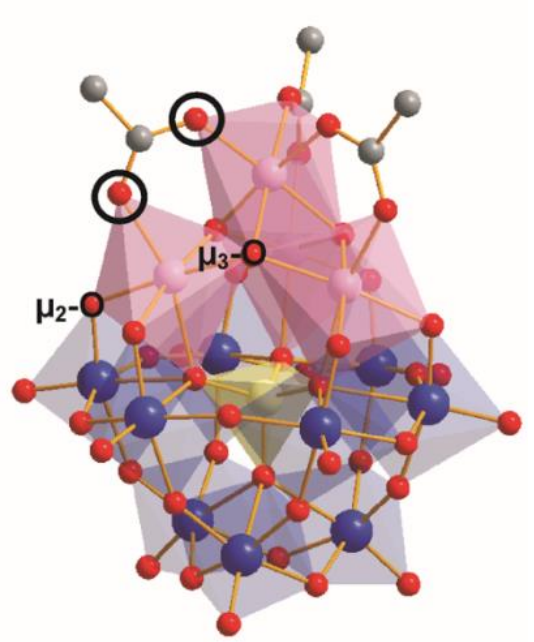

Figure S5. Structures of Keggin POT derivatives $\mathrm{Na}\left\{\mathrm{SiW}_{10} \mathrm{Co}_{2}\right\}_{2}(\mathrm{~A}), \mathrm{Na}\left\{\mathrm{SiW}_{10} \mathrm{Ni}_{2}\right\}_{2}$ (B), $\left\{\mathrm{SiW}_{9} \mathrm{CO}_{4}\right\}(\mathrm{C})$ in the solid state applied for co-crystallization with proteinase K. Color code: dark blue, W; red, O; rose, Co; green, Ni; ivory, Si; grey, C. All POT structures feature labile aquo or acetato ligands (marked by circles) as well as highly nucleophilic and basic bridging oxo-sites. 


\section{Powder X-ray Diffraction}

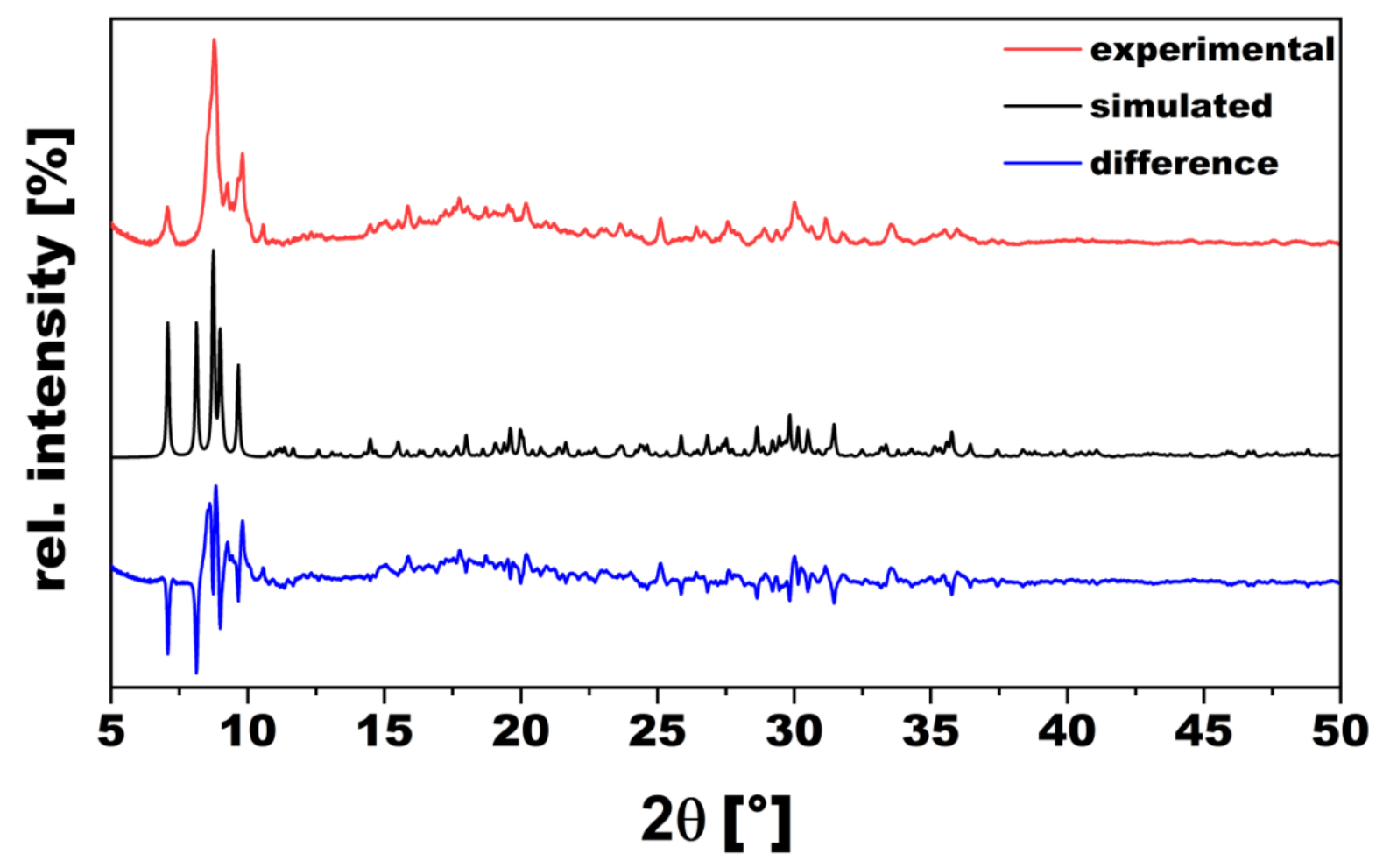

Figure S6. Comparison of the experimental and simulated PXRD patterns of $\mathrm{Na}_{14}[(A-\alpha-$ $\left.\left.\mathrm{SiW}_{10} \mathrm{O}_{37}\right)_{2}\left\{\mathrm{Co}_{4}(\mathrm{OH})_{2}\left(\mathrm{H}_{2} \mathrm{O}\right)_{2}\right\}\right] \cdot 37 \mathrm{H}_{2} \mathrm{O} \mathbf{N a}\left\{\mathrm{SiW}_{10} \mathrm{Co}_{2}\right\}_{2}$. Given the loss of crystal water already occurring at room temperature (please see Figure S3, along with Table S2), the presence of more than one crystalline phase belonging to the investigated POTs can be suggested, which gave rise to the observed difference in the experimental and simulated patterns. 


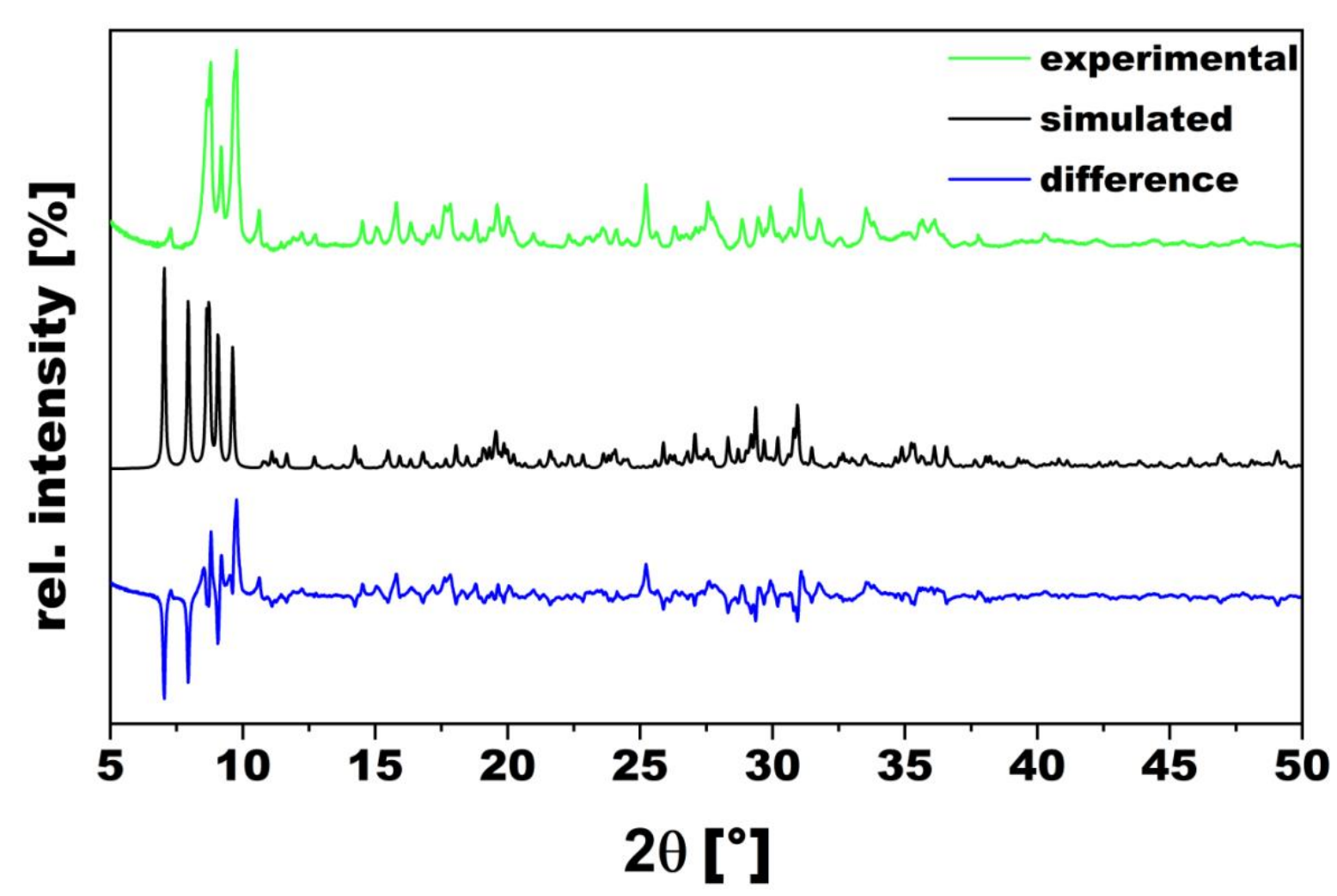

Figure S7. Comparison of the experimental and simulated PXRD patterns of $\mathrm{Na}_{14}[(A-\alpha-$ $\left.\left.\mathrm{SiW}_{10} \mathrm{O}_{37}\right)_{2}\left\{\mathrm{Ni}_{4}(\mathrm{OH})_{2}\left(\mathrm{H}_{2} \mathrm{O}\right)_{2}\right\}\right] \cdot 77.5 \mathrm{H}_{2} \mathrm{O} \mathbf{N a}\left\{\mathrm{SiW}_{10} \mathrm{Ni}_{2}\right\}_{2}$. Given the loss of crystal water already occurring at room temperature (please see Figure S4, along with Table S3), the presence of more than one crystalline phase belonging to the investigated POTs can be suggested, which gave rise to the observed difference in the experimental and simulated patterns. 


\section{UV/Vis Spectroscopy}
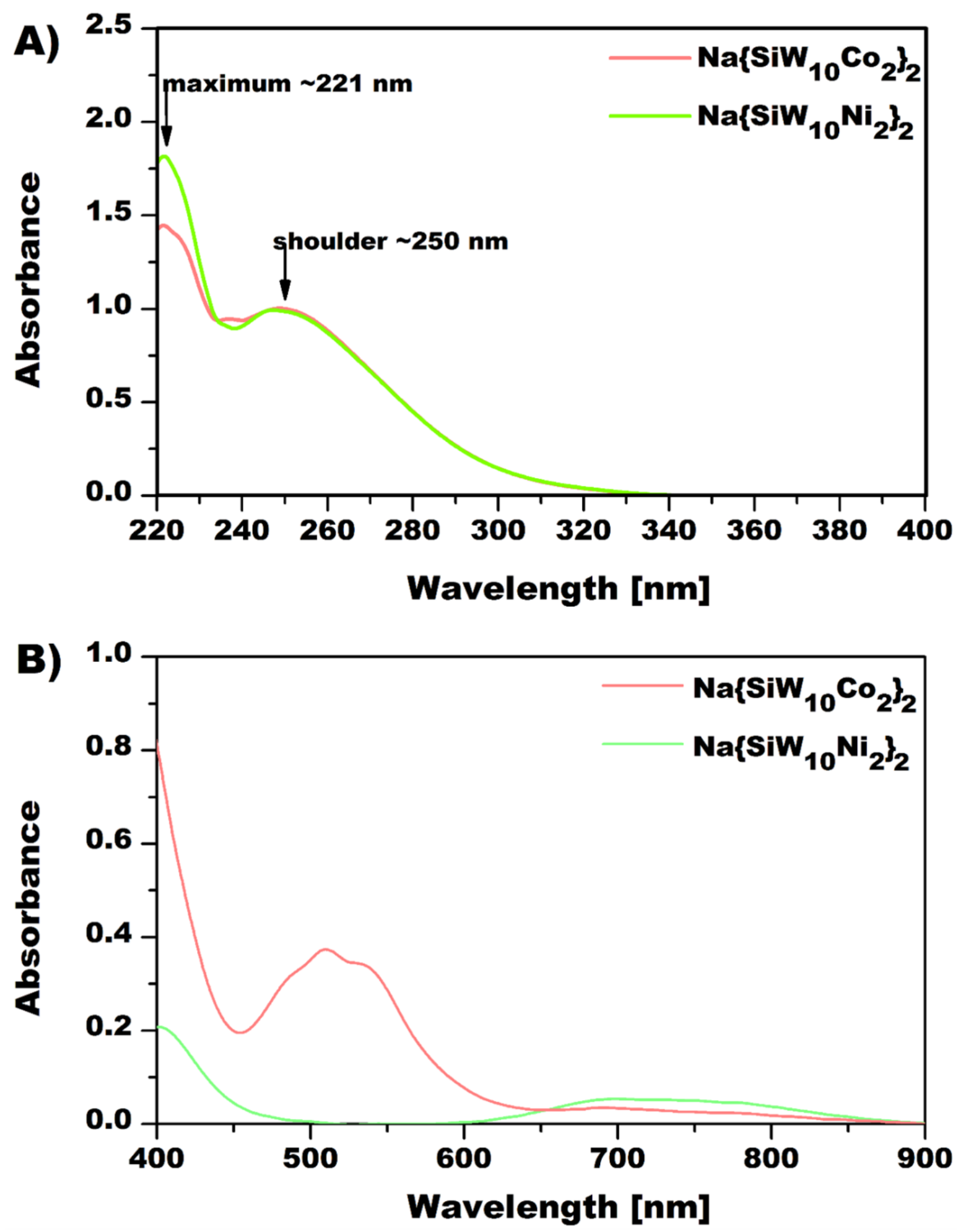

Figure S8. UV/Vis-spectra of $\mathrm{Na}\left\{\mathrm{SiW}_{10} \mathrm{Co}_{2}\right\}$ and $\mathrm{Na}\left\{\mathrm{SiW}_{10} \mathrm{Ni}_{2}\right\}$ in $\mathrm{H}_{2} \mathrm{O}(\mathrm{pH}=6.8$ via $\mathrm{HCl}[1$ $\mathrm{M}]$ ) showing the A) typical $\mathrm{O} \rightarrow \mathrm{W}$ ligand-to-metal charge-transfer with absorption maximum at $\sim 221 \mathrm{~nm}$ and a shoulder at $\sim 250 \mathrm{~nm}[10 \mu \mathrm{M}]$ and $\mathbf{B}$ ) the $\mathrm{d}-\mathrm{d}$ transitions ${ }^{22}$ in the visible-NIR region $[50 \mu \mathrm{M}]$. 

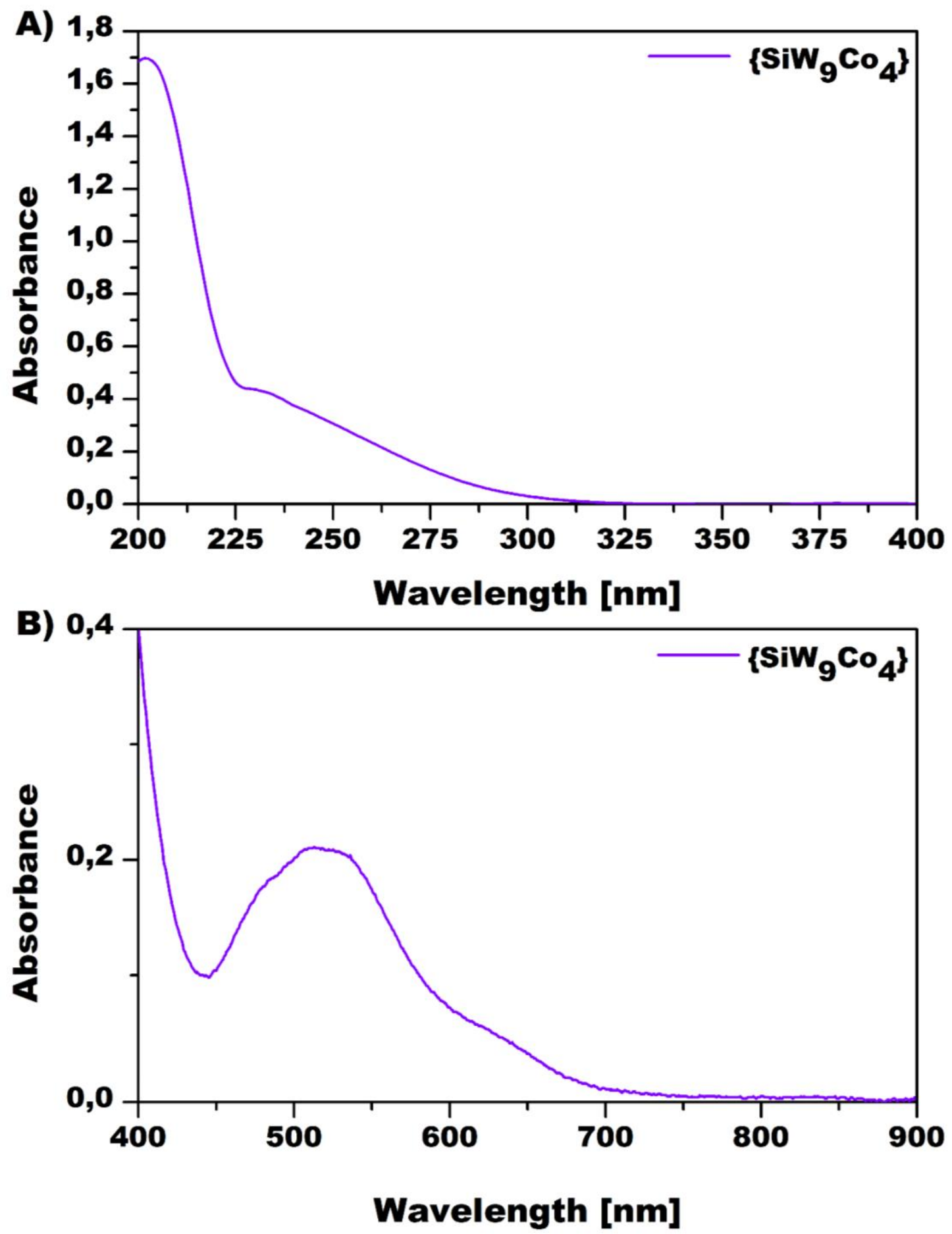

Figure S9. UV/Vis-spectra of $\left\{\mathrm{SiW}_{9} \mathrm{Co}_{4}\right\}$ in $1 \mathrm{M} \mathrm{NaOAc} / \mathrm{AcOH}$ pH 6.0 showing the A) typical $\mathrm{O} \rightarrow \mathrm{W}$ ligand-to-metal charge-transfer with absorption maximum at $\sim 201 \mathrm{~nm}$ and a shoulder at $\sim 250 \mathrm{~nm}([12 \mu \mathrm{M}])$ and $B)$ the $d-d$ transitions $^{22}$ in the visible-NIR region $([40$ $\mu \mathrm{M}])$. 

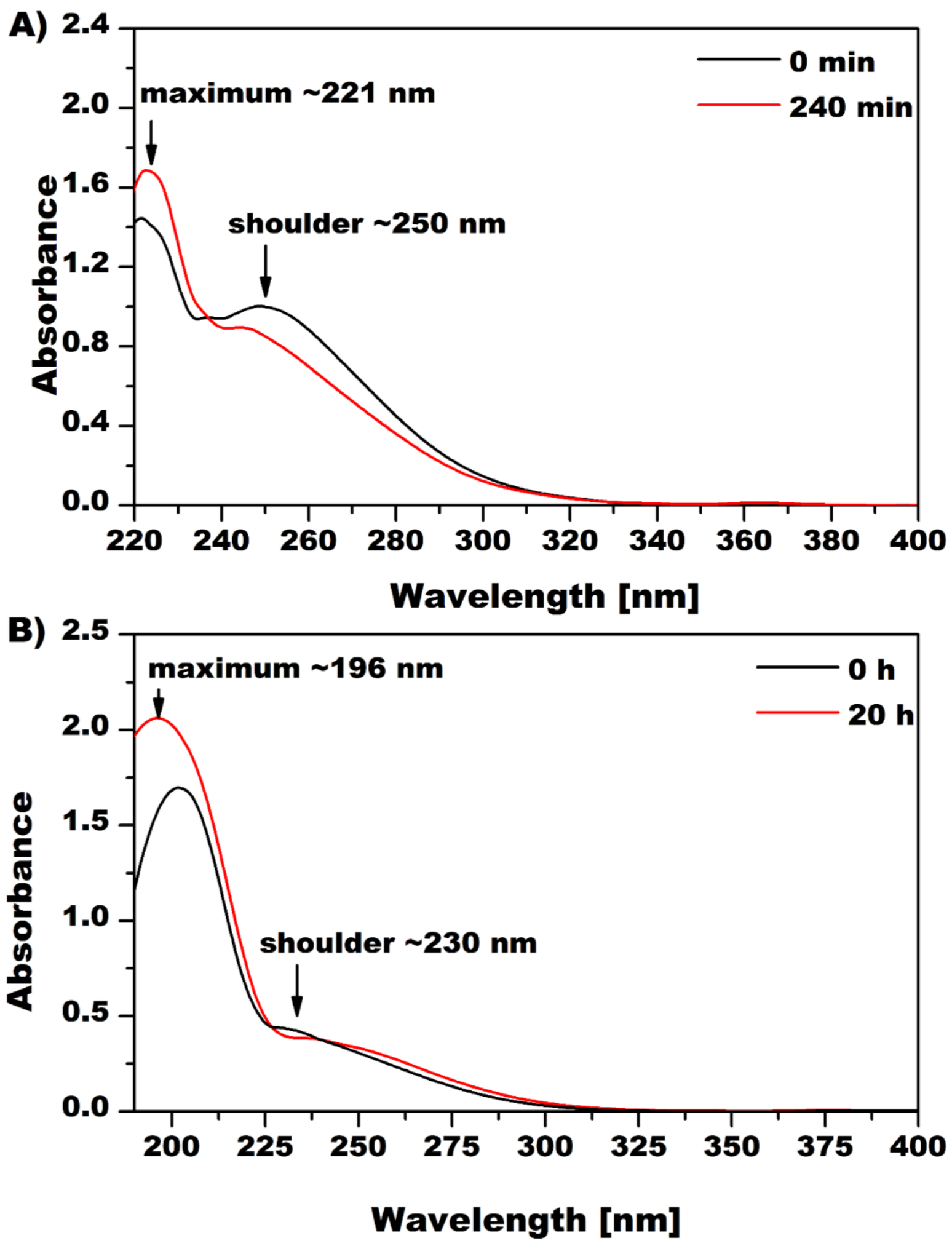

Figure S10. Time-dependent UV/Vis-spectra showing the decreasing shoulder at $\sim 250 \mathrm{~nm}$ in the UV/Vis range of $\mathbf{A}) \mathbf{N a}\left\{\mathrm{SiW}_{10} \mathrm{Co}_{2}\right\}_{2}[10 \mu \mathrm{M}]$ and $\left.\mathbf{B}\right)$ \{SiW $\left.\mathbf{S O}_{4}\right\}[12 \mu \mathrm{M}]$ indicating a rearrangement of the POT framework in $100 \mathrm{mM} \mathrm{NaOAc/AcOH} \mathrm{pH} \mathrm{5.5.}$ 

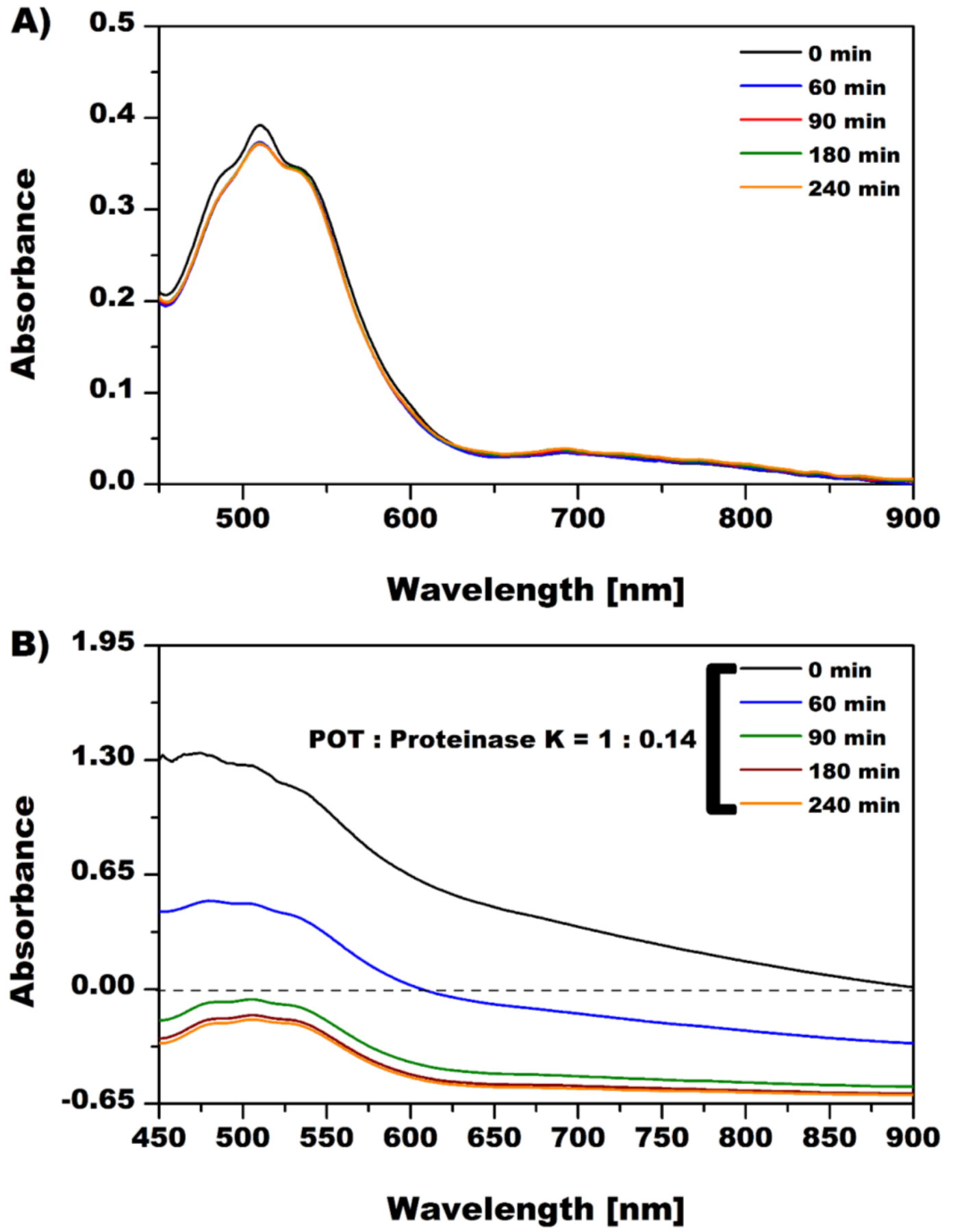

Figure S11. Time-dependent UV/Vis-spectra showing the UV/Vis NIR range of $\mathrm{Na}\left\{\mathrm{SiW}_{10} \mathrm{Co}_{2}\right\}_{2}[50 \mu \mathrm{M}]$ in the A) absence of proteinase $\mathrm{K}$ in $\mathrm{H}_{2} \mathrm{O}(\mathrm{pH}=6.8)$ and the $\left.\mathbf{B}\right)$ presence of proteinase $\mathrm{K}$. The ratio 1:0.14 was chosen to reduce formation of POM - protein precipitates arising from the strong interactions. While the $d-d$ transition band at $\sim 512 \mathrm{~nm}$ corresponding to the octahedrally coordinated $\mathrm{Co}$ (II) metal centers in $\mathrm{Na}\left\{\mathrm{SiW}{ }_{10} \mathrm{Co}_{2}\right\}_{2}$ remain almost unchanged over a time period of $240 \mathrm{~min}$, a drastic change of the absorption can be observed in the presence of the protein suggesting immediate POT-protein interaction resulting in adduct formation and precipitation as shown by a substantial decrease in absorption leading to negative values (dotted line). 


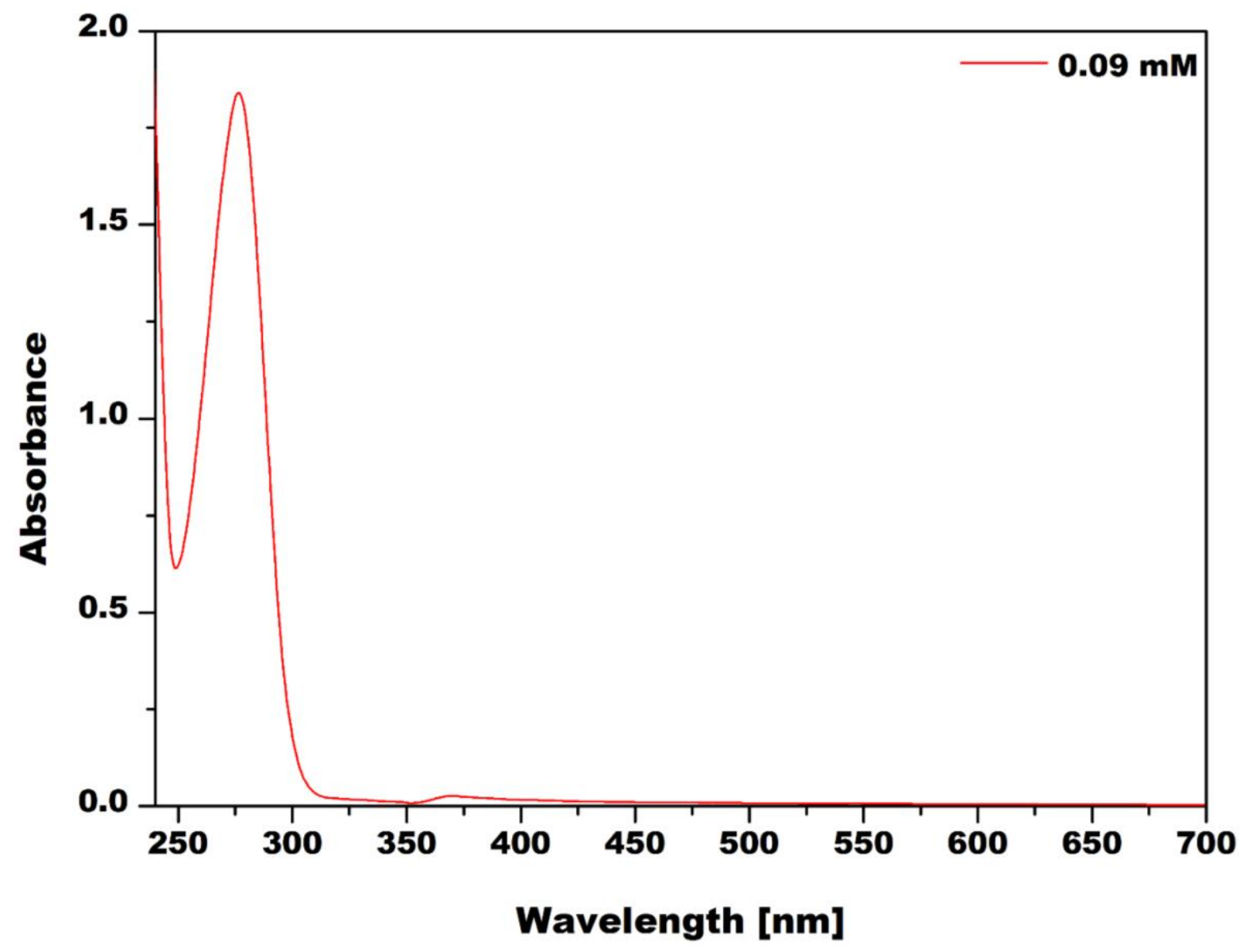

Figure S12. UV/Vis spectrum of proteinase $\mathrm{K}$ in $10 \mathrm{mM}$ Tris/ $\mathrm{HCl} \mathrm{pH} 7.0$ showing the pronounced band at $276 \mathrm{~nm}$ attributed to the presence of tyrosine side chains. ${ }^{23}$ 


\section{ESI MS}

\section{A) in $\mathrm{H}_{2} \mathrm{O}$ fresh}
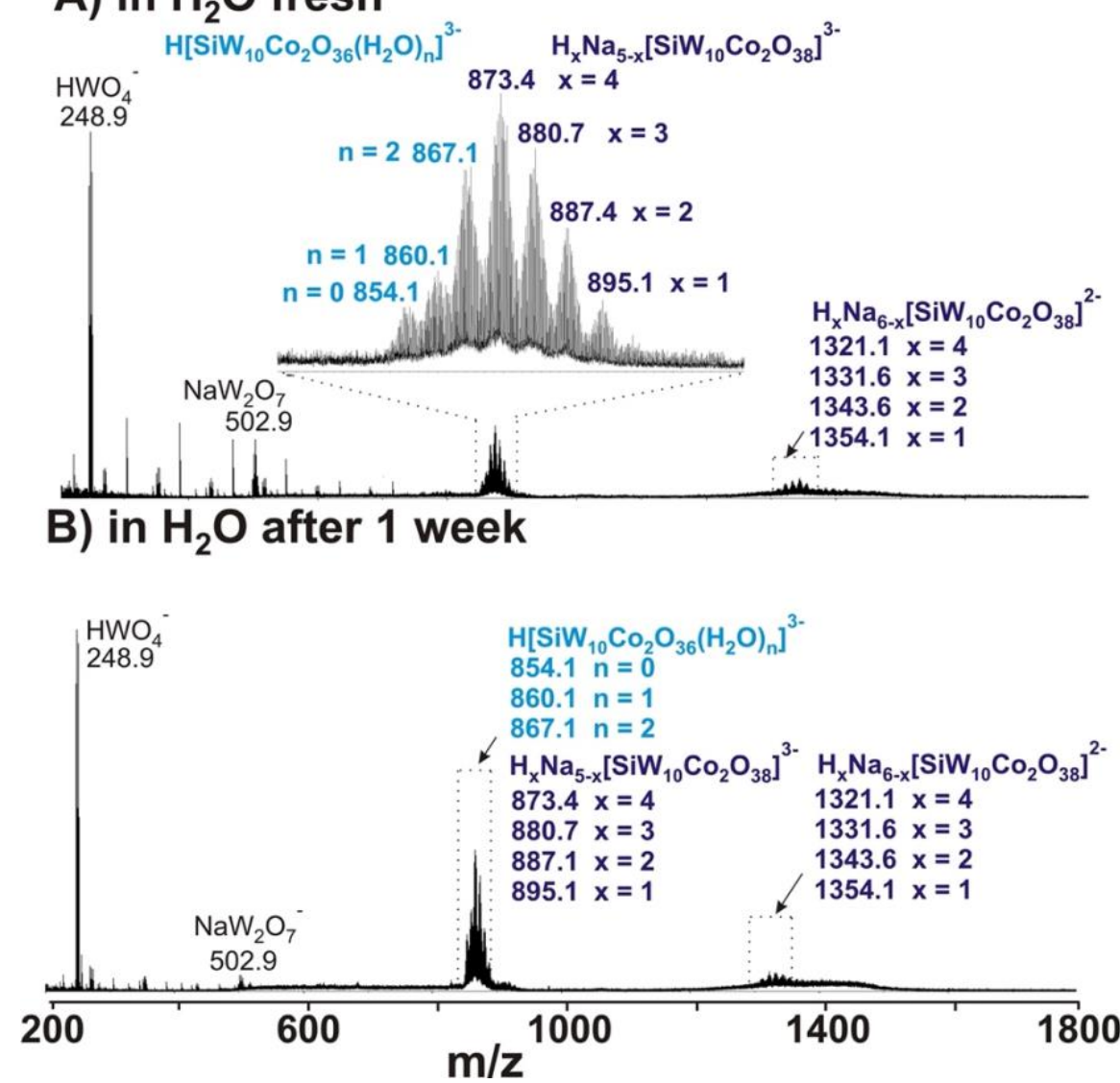

\section{C) in $\mathrm{NaOAc} / \mathrm{AcOH}$ pH 5.5 fresh}

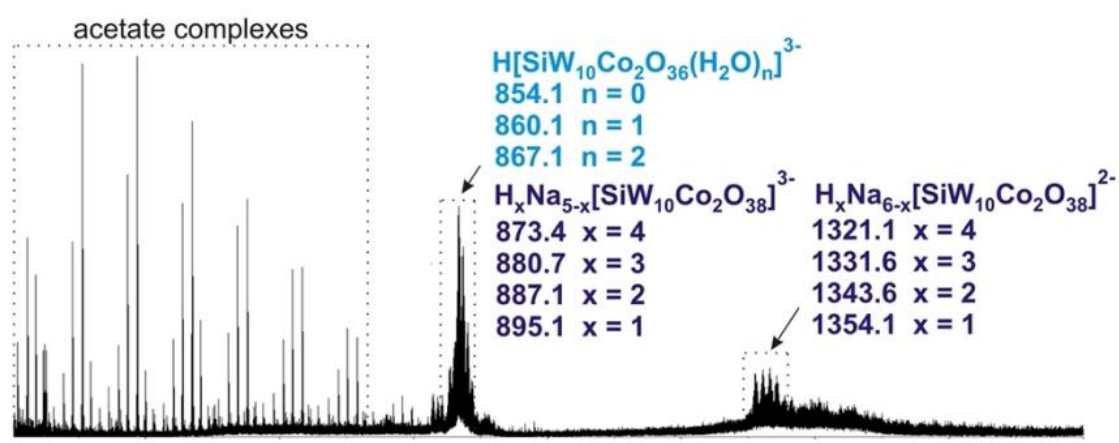

\section{D) in NaOAc / AcOH pH 5.5 after 1 week}

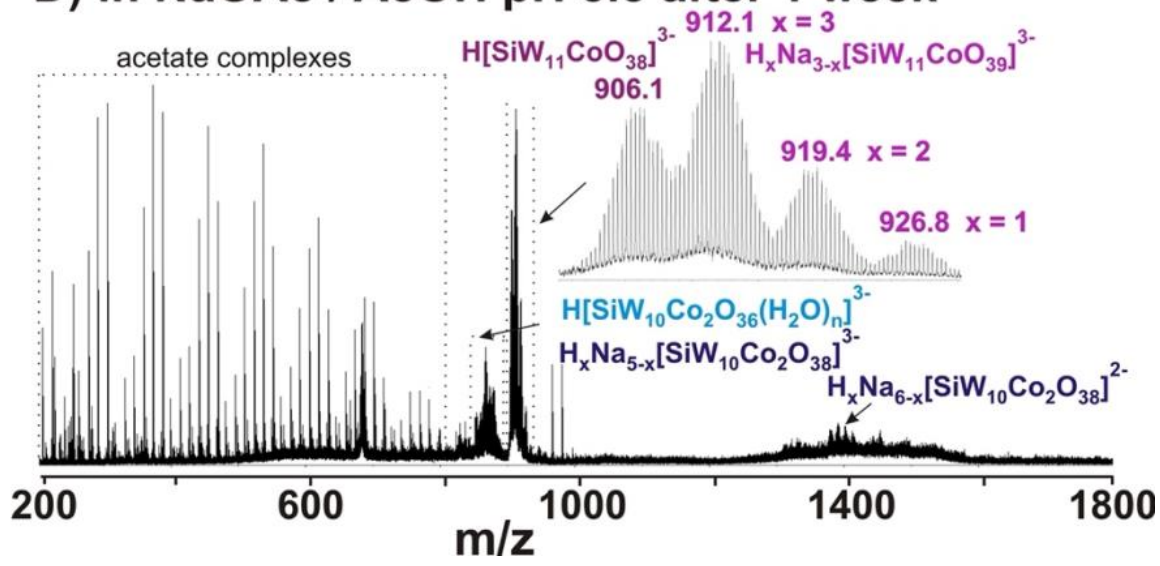

Figure S13. ESI mass spectrum of $\mathbf{N a}\left\{\mathrm{SiW}_{10} \mathrm{Co}_{2}\right\}_{2}$ recorded in negative mode in the range 200 to $1800 \mathrm{~m} / \mathrm{z} \mathbf{A}$ ) in a freshly prepared and $\mathbf{B}$ ) in an aqueous solution aged for one week at room temperature; $\mathbf{C}$ ) in a freshly prepared and $\mathbf{D}$ ) in a sodium acetate buffer ( $\mathrm{pH} 5.5$ ) solution aged for one week at room temperature; for anions $\mathrm{H}\left[\mathrm{SiW}_{10} \mathrm{Co}_{2} \mathrm{O}_{36}\left(\mathrm{H}_{2} \mathrm{O}\right)_{n}\right]^{3-}, \mathrm{H}_{x} \mathrm{Na}_{5-x}\left[\mathrm{SiW}_{10} \mathrm{Co}_{2} \mathrm{O}_{38}\right]^{3-}$ and $\mathrm{H}_{x} \mathrm{Na}_{6-x}\left[\mathrm{SiW}_{10} \mathrm{Co}_{2} \mathrm{O}_{38}\right]^{2-}$ values $\mathrm{n}$ and $\mathrm{x}$ are the same as in A) - C). 


\section{A) in $\mathrm{H}_{2} \mathrm{O}$ fresh}

$\mathrm{H}\left[\mathrm{SiW}_{10} \mathrm{Ni}_{2} \mathrm{O}_{36}\left(\mathrm{H}_{2} \mathrm{O}\right)_{n}\right]^{3-} \mathrm{H}_{\mathrm{x}} \mathrm{Na}_{5-x}\left[\mathrm{SiW}_{10} \mathrm{Ni}_{2} \mathrm{O}_{38}\right]^{3-}$ $\mathrm{n}=2865.4$

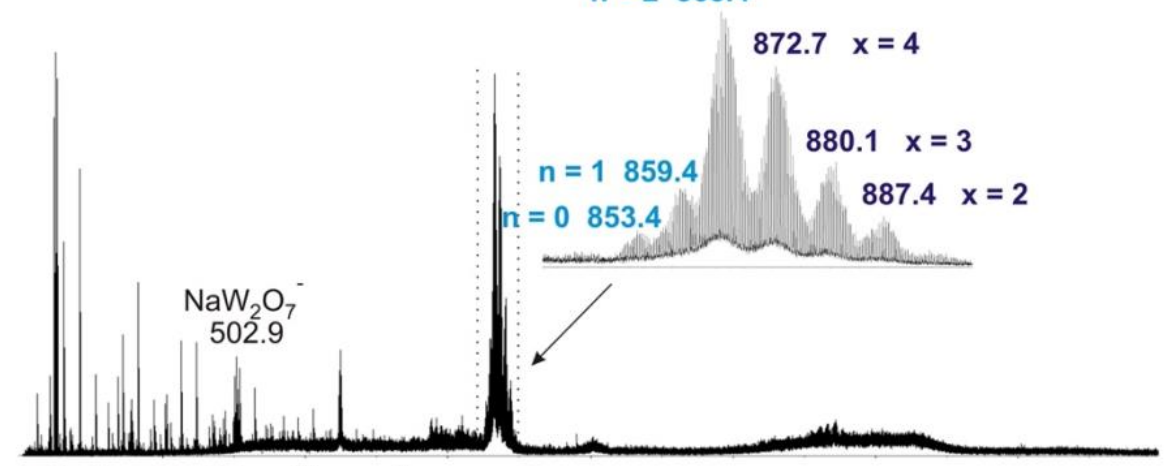

\section{B) in $\mathrm{H}_{2} \mathrm{O}$ after 1 week}

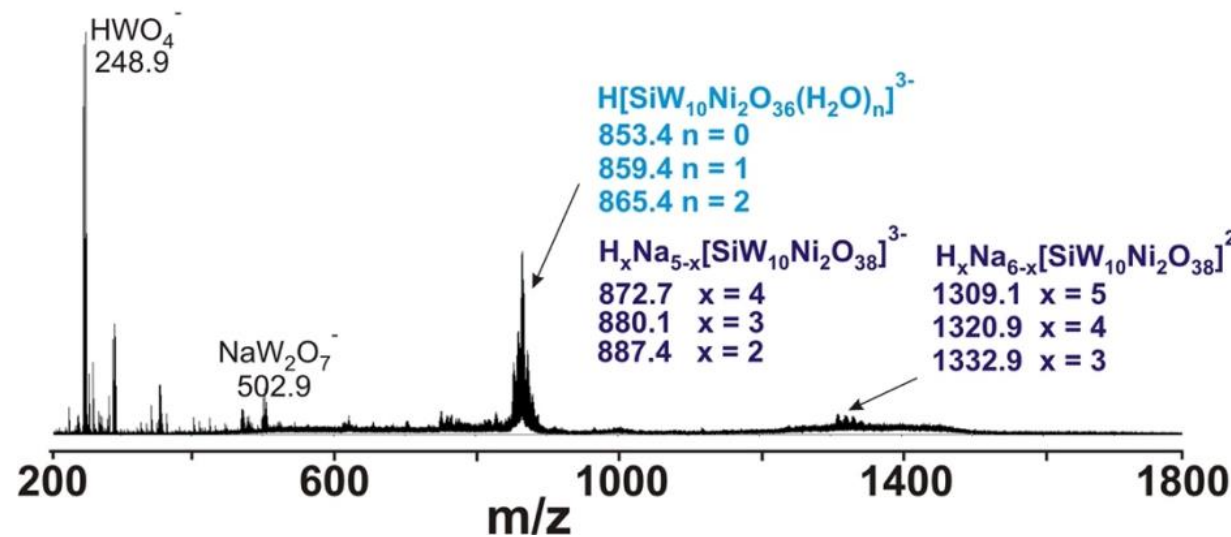

C) in NaOAc / AcOH pH 5.5

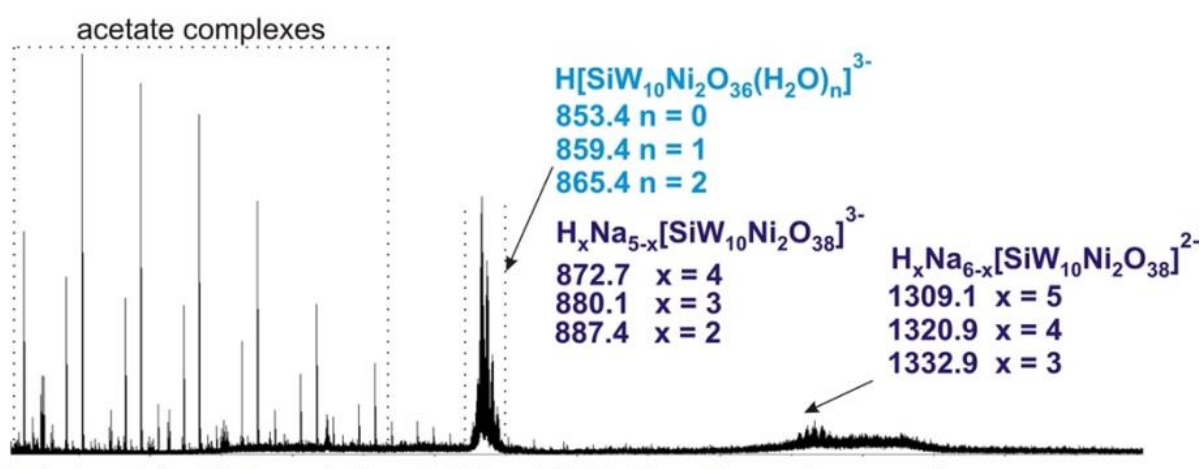

\section{D) in $\mathrm{NaOAc} / \mathrm{AcOH}$ pH 5.5 after 1 week}

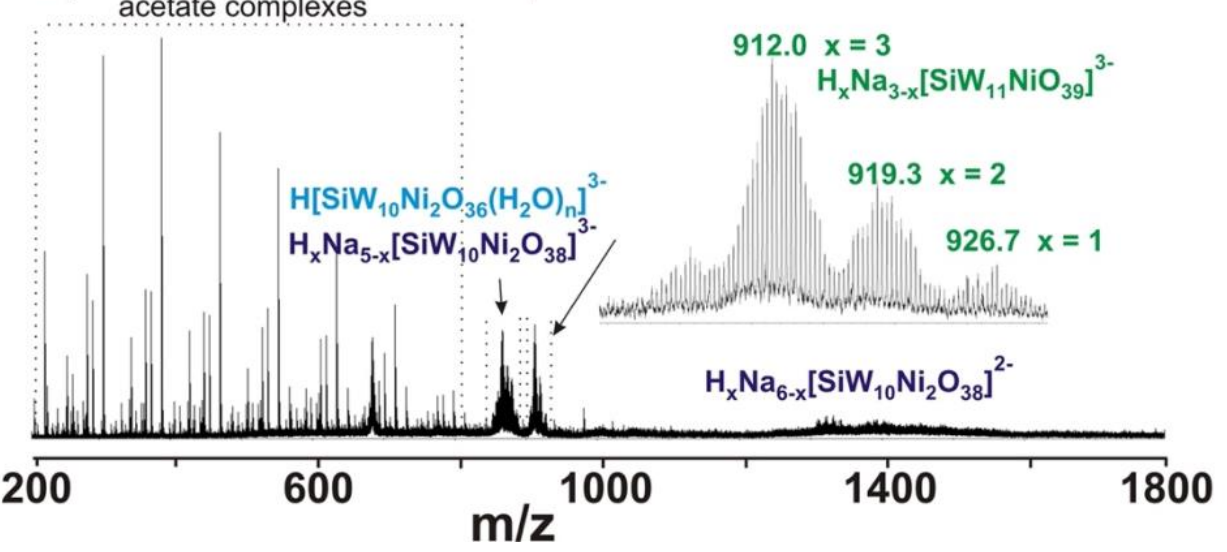

Figure S14. ESI mass spectrum of $\mathbf{N a}\left\{\mathrm{SiW}_{10} \mathbf{N i}_{2}\right\}_{2}$ recorded in negative mode in the range 200 to $1800 \mathrm{~m} / \mathrm{z} \mathbf{A}$ ) in a freshly prepared and $\mathbf{B}$ ) in an aqueous solution aged for one week at room temperature; $\mathbf{C}$ ) in a freshly prepared and $\mathbf{D}$ ) in a sodium acetate buffer ( $\mathrm{pH} 5.5$ ) solution aged for one week at room temperature, for anions $\mathrm{H}\left[\mathrm{SiW}_{10} \mathrm{Ni}_{2} \mathrm{O}_{36}\left(\mathrm{H}_{2} \mathrm{O}\right)_{n}\right]^{3-}, \mathrm{H}_{x} \mathrm{Na}_{5-x}\left[\mathrm{SiW}_{10} \mathrm{Ni}_{2} \mathrm{O}_{38}\right]^{3-}$ and $\mathrm{H}_{x} \mathrm{Na}_{6-x}\left[\mathrm{SiW}_{10} \mathrm{Ni}_{2} \mathrm{O}_{38}\right]^{2-}$ values $\mathrm{n}$ and $x$ are the same as in A) - C). 
Scheme S1. Rearrangement pathway for dimeric sandwich POTs based on time-dependent ESI MS (Figures S13, S14) and UV/vis studies (Figures S10, S11). Starting from the tetrasubstituted dimeric sandwich POT $\mathbf{N a}\left\{\mathrm{SiW}_{10} \mathbf{M}_{2}\right\}_{2}$, disubstituted monomeric species $\left\{\right.$ SiW $_{10} \mathbf{M}_{2}$ \} after 1) 1 day in $\mathrm{H}_{2} \mathrm{O}$ and 2) 1 day in $100 \mathrm{mM} \mathrm{NaOAc/AcOH}(\mathrm{pH} \mathrm{5.5).} \mathrm{The}$ disubstituted monomeric representatives further hydrolyze to monosubstituted monomers $\boldsymbol{\alpha}$ $\left\{\mathrm{SiW}_{11} \mathrm{M}\right\}$ after incubation 3) in $100 \mathrm{mM} \mathrm{NaOAc} / \mathrm{AcOH}$ (pH 5.5) for one week, whereas no change is observed in the pristine disubstituted monomers $\left\{\mathbf{S i W} \mathbf{W}_{\mathbf{1 0}} \mathbf{M}_{\mathbf{2}}\right\}$ after 4 ) one week in $\mathrm{H}_{2} \mathrm{O}\left(\mathrm{M}=\mathrm{Co}^{\prime \prime}, \mathrm{Ni}^{\prime \prime}\right)$. Black, blue and red spheres represent the $\mathrm{Si}^{i \mathrm{~V}}, \mathrm{M}^{\prime \prime}$ and oxygen ions, respectively. Magenta octahedra for $\left\{\mathrm{WO}_{6}\right\}$. The exact pathway for $\left\{\mathrm{SiW}_{9} \mathrm{Co}_{4}\right\}$ cannot be identified by ESI-MS due to the presence of the acetate group in the POT structure; however, the time-dependent UV/Vis spectra (Figure S10B) in sodium acetate buffer clearly indicate POT rearrangement.

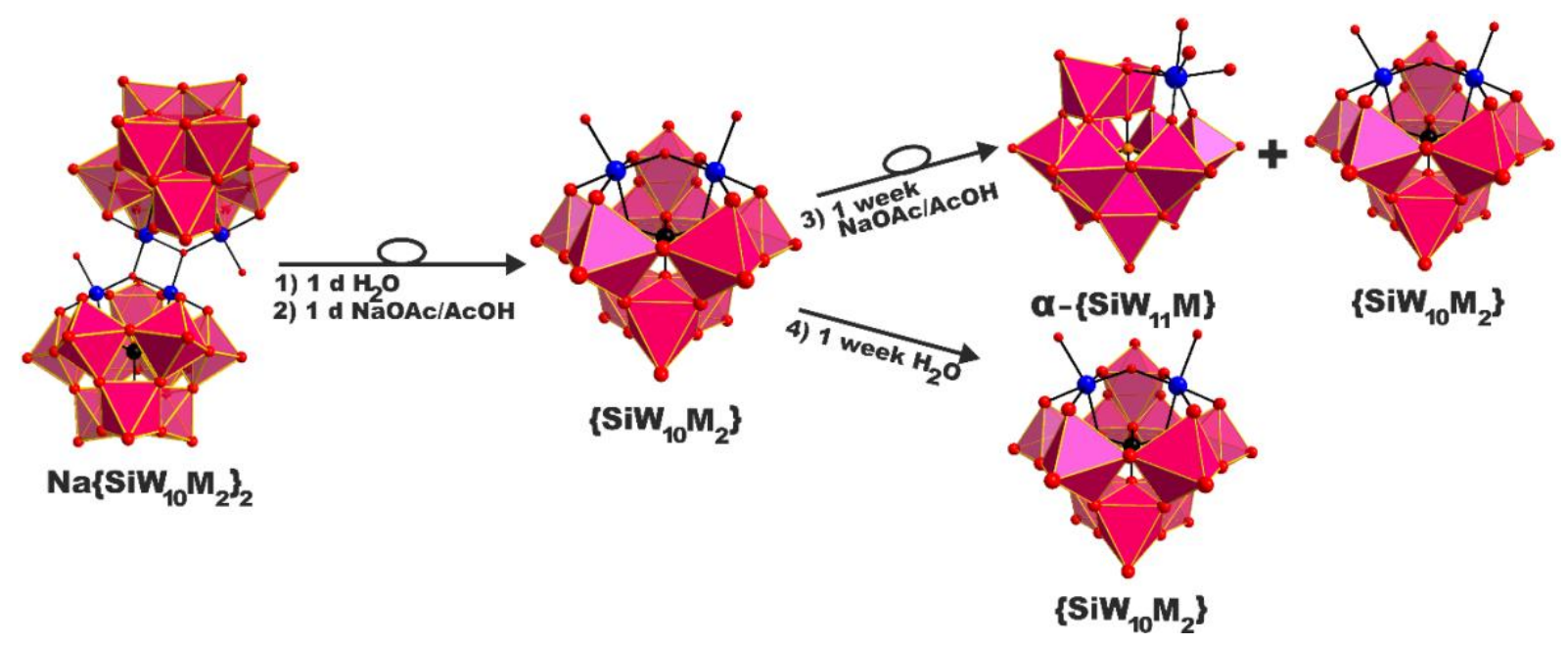

\section{POT - Proteinase K co-crystallization}

\subsection{Preparation of Proteinase K for crystallization}

Standard chemicals at least of analytical grade (Sigma Aldrich) were used throughout this study. Proteinase $\mathrm{K}$ from Tritirachium album was purchased from Sigma-Aldrich (P6556), dissolved in $10 \mathrm{mM}$ Tris/HCl pH 7.0, $0.05 \%(\mathrm{~m} / \mathrm{v}) \mathrm{NaN}_{3}$ to obtain a $100 \mathrm{~g} / \mathrm{L}$ protein solution and centrifuged for $15 \mathrm{~min}$ at $20817 \mathrm{xg}(14000 \mathrm{rpm})$ to spin down traces of insoluble material. The supernatant was considered sufficiently pure for crystallization trials without further purification (Figures S15, S16). 


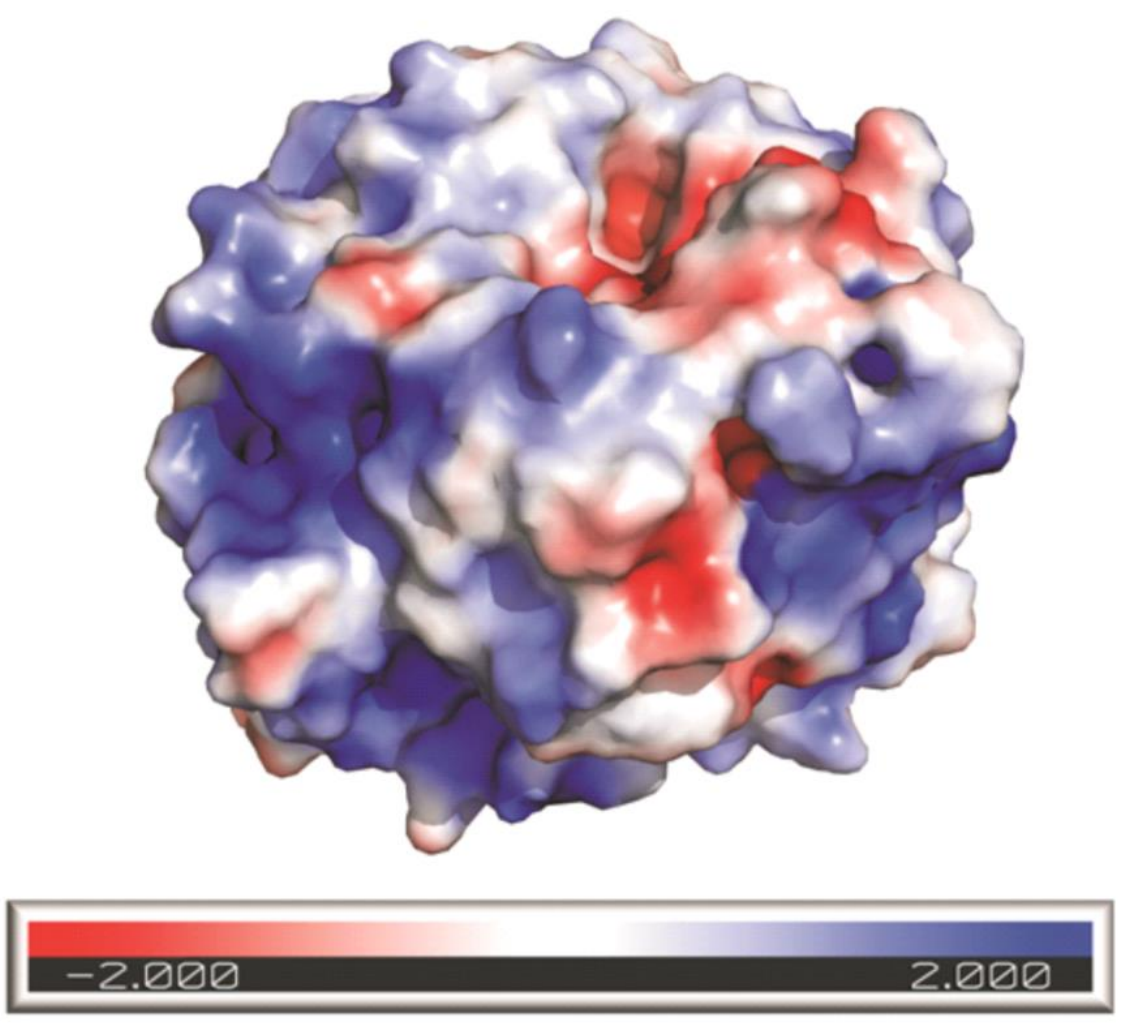

Figure. S15. Electrostatic surface representation of proteinase K. The surface of proteinase $\mathrm{K}$ is dominated by positive patches shown in blue. Negative patches are colored in red and patches with no preferred polarity in white. The polarity range is given in the color bar (in units of $\left.k_{B} T / e\right)$. Negatively charged POTs are supposed to interact with the protein surface close to the blue positively charged cavities. 


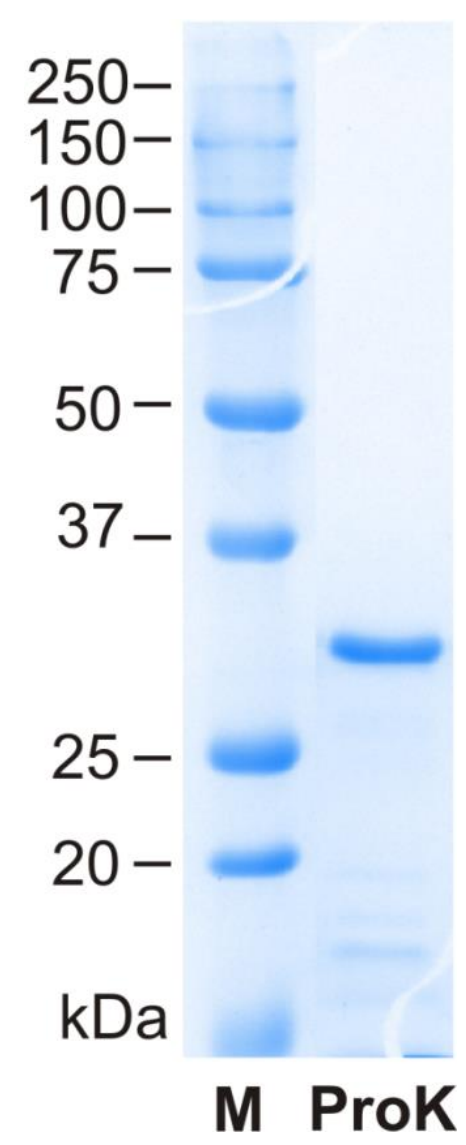

Figure. S16. SDS-PAGE of proteinase $\mathrm{K}$. The protein band is sufficiently pure and migrates at the expected molecular weight of $28.93 \mathrm{kDa}$. Lane: M: Precision Plus Protein Standard (BIO-RAD).

\subsection{Preparation of Polyoxotungstate-Proteinase K co-crystals}

Crystals with substituted Keggin POT derivatives were obtained by the hanging-drop vapor diffusion technique in $100 \mathrm{mM} \mathrm{NaOAc/AcOH} \mathrm{pH} 5.5$ with 0.7-1.1 $\mathrm{M}\left(\mathrm{NH}_{4}\right)_{2} \mathrm{SO}_{4}$ as a precipitant (reservoir solution, $750 \mu \mathrm{L}$ ). For stock solutions, $\mathbf{N a}\left\{\mathrm{SiW}_{10} \mathrm{Co}_{2}\right\}_{2}$ and $\mathrm{Na}\left\{\mathrm{SiW}_{10} \mathrm{Ni}_{2}\right\}_{2}$ were dissolved in water, $\left\{\mathrm{SiW}_{9} \mathrm{Co}_{4}\right\}$ was dissolved in $1 \mathrm{M} \mathrm{NaOAc} / \mathrm{AcOH} \mathrm{pH}$ 6.0 to prevent loss of the acetato ligands. Drops were set up from $1 \mu \mathrm{L}$ of $100 \mathrm{~g} / \mathrm{L}(3.5 \mathrm{mM})$ proteinase $\mathrm{K}$ stock solution, $0.5 \mu \mathrm{L}$ of $5 \mathrm{mM}$ Keggin POT stock solution and $1 \mu \mathrm{L}$ of reservoir solution. After few hours, a fine protein precipitate formed due to unspecific aggregation, from which spindle-shaped crystals appeared after 2 weeks. These crystals effected resolubilization of precipitated protein, which then fed crystal growth leading to 50-100 $\mu \mathrm{m}$ crystals. An alternative crystallization condition consisted of $100 \mathrm{mM} \mathrm{NaOAc/AcOH} \mathrm{pH} 5.5$ with 0.3-0.7 $\mathrm{M}\left(\mathrm{NH}_{4}\right)_{2} \mathrm{SO}_{4}$ and $0.5 \mathrm{M}$ betaine. The zwitterionic additive betaine was successfully applied to prevent the strong unspecific charge-driven aggregation observed for concentrated POT-protein mixtures in the acidic milieu and facilitate the growth of large, ordered crystals, which helped in co-crystallization with $\mathbf{N a}\left\{\mathbf{S i W}_{\mathbf{1}_{0}} \mathbf{N i}_{\mathbf{2}}\right\}_{2}$. Protein crystals were harvested in nylon loops, quickly wiped through a cryo-protectant solution containing $15 \%$ $(\mathrm{v} / \mathrm{v})$ glycerol and flash-frozen in liquid nitrogen. The crystals were analyzed with a Bruker D8 VENTURE X-ray diffractometer equipped with a multilayer monochromator, a PHOTON II 
charge-integrating pixel array detector, a $\mathrm{CuK}_{\alpha}$ Incoatec Microfocus (sealed tube) and a Kryoflex cooling device. For data collection and refinement statistics refer to Table S6. Note that POT : protein ratios other than $1.4: 1$ either resulted in no crystal formation or precipitates.

\section{3. $\quad$ X-ray data collection, structure solution and refinement}

After extraction of the measurement parameters by Tim Grüne's sfrmtools (https://homepage.univie.ac.at/tim.gruene/research/programs/conv/sfrmtools/), X-ray data were processed with $\mathrm{XDS}^{24}$, and the structures were solved by molecular replacement with the PDB protein structure 1ic6 using PHASER $^{25}$ within the PHENIX $^{26}$ program suite. Structures were refined with phenix.refine (PHENIX) and manually fixed in $\operatorname{Coot}^{27}$. After the first refinement steps, it became obvious also by crystal structure analysis that all Keggin derivatives had undergone structural rearrangement to the monosubstituted anions $\alpha$ -

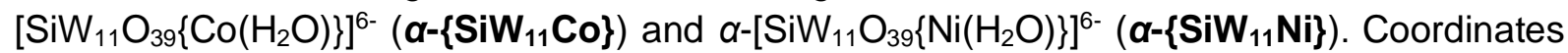
and restraints files for the $\alpha$-Keggin structure (from PDB entry) were created using phenix.elbow (PHENIX) and the POT ligands were modelled in Coot. Parameters of data collection are given in Table S6, together with the refinement statistics. The $B$-factors for the structures with Keggin-POTs $\alpha-\left\{\mathrm{SiW}_{11} \mathrm{Co}\right\}$ and $\alpha-\left\{\mathrm{SiW}_{11} \mathrm{Ni}\right\}$ do not significantly differ from the corresponding protein $B$-factors, supporting the proper refinement of $\mathrm{X}$-ray structures and the covalent bond formation between POT and protein.

Table S6. X-ray structural analysis, data processing and refinement. The PDB entry 7A9F contains $\alpha-\left\{\mathrm{SiW}_{11} \mathrm{Co}\right\}$, which arose from $\alpha-\left\{\mathrm{SiW}_{10} \mathrm{Co}_{2}\right\}_{2}$ during the crystallization in the buffer and PDB entry 7 A9M contains $\alpha-\left\{\mathrm{SiW}_{11} \mathrm{Co}\right\}$, which was formed from $\alpha-\left\{\mathrm{SiW}_{9} \mathrm{Co}_{4}\right\}(\mathrm{OAC})_{3}$ during crystallization in the buffer.

\begin{tabular}{|c|c|c|c|}
\hline Keggin POT & $\alpha-\left[\mathrm{SiW}_{11} \mathrm{Co}\right]^{6-}$ & $\alpha-\left[\mathrm{SiW}_{11} \mathrm{Ni}^{6-}\right.$ & $\alpha-\left[\mathrm{SiW}_{11} \mathrm{Co}^{6-}\right.$ \\
\hline Crystal data & 85 A 1 prok $25 c 1$ & $\begin{array}{l}85 \text { A } 4 \text { betain } \\
\text { prok27a2 }\end{array}$ & $\begin{array}{l}85 \text { A } 627 \\
\text { prok27b3 }\end{array}$ \\
\hline Space group & $\mathrm{P} 4_{3} 2{ }_{1} 2$ & $\mathrm{P} 4_{3} 2_{12}$ & $\mathrm{P} 4{ }_{3} 2_{1} 2$ \\
\hline$a, b, c,[\AA]$ & $\begin{array}{c}\text { 68.13, 68.13 } \\
102.79\end{array}$ & $\begin{array}{c}68.01,68.01 \\
102.58\end{array}$ & $\begin{array}{c}\text { 68.05, 68.05 } \\
102.47\end{array}$ \\
\hline$\alpha, \beta, y\left[^{\circ}\right]$ & $90,90,90$ & $90,90,90$ & $90,90,90$ \\
\hline Molecules per asymmetric unit & 1 & 1 & 1 \\
\hline Matthews coefficient $\left[\AA^{3} \mathrm{Da}^{-1}\right]$ & 1.90 & 1.89 & 1.89 \\
\hline Solvent content [\%] & 0.353 & 0.349 & 0.350 \\
\hline Maximum resolution [Å] & 1.62 & 1.62 & 1.62 \\
\hline \multicolumn{4}{|l|}{ Data collection and processing } \\
\hline Wavelength [Å] & 1.54184 & 1.54184 & 1.54184 \\
\hline Resolution limits [Å] & $\begin{array}{c}41.03-1.62 \\
(1.678-1.62)\end{array}$ & $\begin{array}{c}34.01-1.62 \\
(1.678-1.62)\end{array}$ & $\begin{array}{c}40.93-1.62 \\
(1.678-1.62)\end{array}$ \\
\hline Number of observed reflections & $272438(5646)$ & $365494(7386)$ & $364316(7314)$ \\
\hline Number of unique reflections & $51332(2798)$ & $56070(3962)$ & 56364 (4059) \\
\hline Redundancy & $5.3(2.1)$ & $6.5(1.9)$ & $6.5(1.8)$ \\
\hline$R_{\text {p.i.m. }}{ }^{[a]}$ & $0.0456(0.5173)$ & $\begin{array}{l}0.03254 \\
(0.4144)\end{array}$ & $0.0205(0.1954)$ \\
\hline
\end{tabular}




\begin{tabular}{|c|c|c|c|}
\hline $\boldsymbol{R}_{\text {merge }}{ }^{[\mathrm{b}]}$ & $0.09651(0.6594)$ & $0.08(0.5361)$ & $\begin{array}{l}0.05134 \\
(0.2387)\end{array}$ \\
\hline $\mathrm{CC}_{1 / 2}$ & $0.994(0.551)$ & $0.997(0.704)$ & $0.999(0.91)$ \\
\hline $\mathrm{CC}^{*}$ & $0.999(0.843)$ & $0.999(0.909)$ & $1(0.976)$ \\
\hline Completeness [\%] & $87.71(47.83)$ & $96.02(68.23)$ & $99.79(99.84)$ \\
\hline$<|/ \sigma|>$ & $14.19(1.21)$ & $16.66(1.33)$ & $23.82(2.69)$ \\
\hline \multicolumn{4}{|l|}{ Anomalous signal } \\
\hline SigAno [c] & 1.434 & 1.225 & 1.519 \\
\hline AnomCorr ${ }^{[d]}[\%]$ & 51 & 38 & 55 \\
\hline \multicolumn{4}{|l|}{ Refinement statistics } \\
\hline Resolution [Å] & $41.03-1.62$ & $34.01-1.62$ & $40.93-1.62$ \\
\hline Reflections used & 51539 (2795) & $56064(3958)$ & $56362(4058)$ \\
\hline $\boldsymbol{R}_{\text {work }}{ }^{[\mathrm{e}]}[\%]$ & $0.1428(0.2687)$ & $\begin{array}{c}0.1469 \\
(0.2509)\end{array}$ & $0.1317(0.1735)$ \\
\hline $\boldsymbol{R}_{\text {free }}{ }^{[\mathrm{f}]}[\%]$ & $0.1747(0.3078)$ & $\begin{array}{l}0.1889 \\
(0.2944)\end{array}$ & $0.1666(0.2254)$ \\
\hline Number of water molecules & 356 & 395 & 376 \\
\hline Average $B$-factor $\left[\AA^{2}\right]$ & 11.17 & 13.06 & 12.14 \\
\hline$B$-factor : Protein chain & 9.44 & 9.15 & 8.75 \\
\hline $\begin{array}{c}\text { B-factor : ligands (POTs, } \\
\text { sulphate) }\end{array}$ & 13.50 & 48.90 & 39.09 \\
\hline$B$-factor : water molecules & 20.32 & 23.26 & 22.38 \\
\hline \multicolumn{4}{|l|}{ Ramachandran plot ${ }^{[g]}$} \\
\hline Most favoured regions [\%] & 97.11 & 97.47 & 97.11 \\
\hline Additional allowed regions [\%] & 2.53 & 2.53 & 2.53 \\
\hline Disallowed regions [\%] & 0.36 & 0 & 0.36 \\
\hline PDB ID & 7A9F & 7A9K & 7A9M \\
\hline
\end{tabular}

[a] $R_{\text {p.i.m. }}=\Sigma_{h k}\{1 /[N(h k)-1]\}^{1 / 2} \cdot \Sigma_{i} \mid l_{i}(h k)-\langle(h k n\rangle| / \Sigma_{h k \mid \Sigma_{i}} l_{i}(h k)$, with $l_{i}(h k)$ being the th observation of reflection $h k l$, and $\langle(h k \|\rangle$ the weighted average intensity for all observations of reflection $h k l$.

[b] $R_{\text {merge }}=\Sigma_{h k} \Sigma_{i}|l i(h k) i-\langle/(h k \Lambda)\rangle| / \Sigma_{h k} \Sigma_{i} l_{i}(h k)_{i}$.

[c] Mean anomalous difference in units of estimated standard deviation $(|F(+)|-|F(-)| / \sigma)$ with the structure factors $F(+)$ and $F(-)$ obtained from the merged intensity observations in each parity class.

[d] Percent correlation between random half-sets of anomalous intensity differences.

[e] $R_{\text {work }}=\Sigma\left|F_{\text {calc }}\right|-\left|F_{\text {obs }}\right| / \Sigma\left|F_{\text {obs }}\right| \times 100$, where $F_{\text {calc }}$ and Fobs are the calculated and observed structure factor amplitudes, respectively.

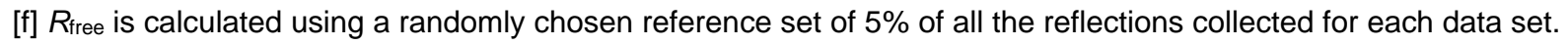

[g] Calculated with Coot. ${ }^{27}$

\subsection{Binding positions of Keggin anions}

The two main interaction positions of Keggin-POTs on the surface of proteinase $\mathrm{K}$ (Figue S17) are involved in various interaction modes with non-polar, positively and negatively polarized surface patches. The two Keggin POTs substituted by $\mathrm{Co}^{\prime \prime}$ and $\mathrm{Ni}^{\prime \prime}$ (monosubstituted $\boldsymbol{\alpha}-\left\{\mathrm{SiW}_{11} \mathrm{Co}\right\}$ and $\boldsymbol{\alpha}-\left\{\mathrm{SiW}_{11} \mathbf{N i}\right\}$ ) shared a common position on the proteinase $\mathrm{K}$ surface, forming a covalent bond to the aspartate side-chain D207 (position 1) (Figure S18A). The bridging contacts to three different protein molecules are depicted in Fig. S10A. The Keggin anions were also observed in the vicinity of the residue S45 (position 2) in a second common site. In this position, the POT clusters interacted with two distinct protein molecules (Figure S18B). 


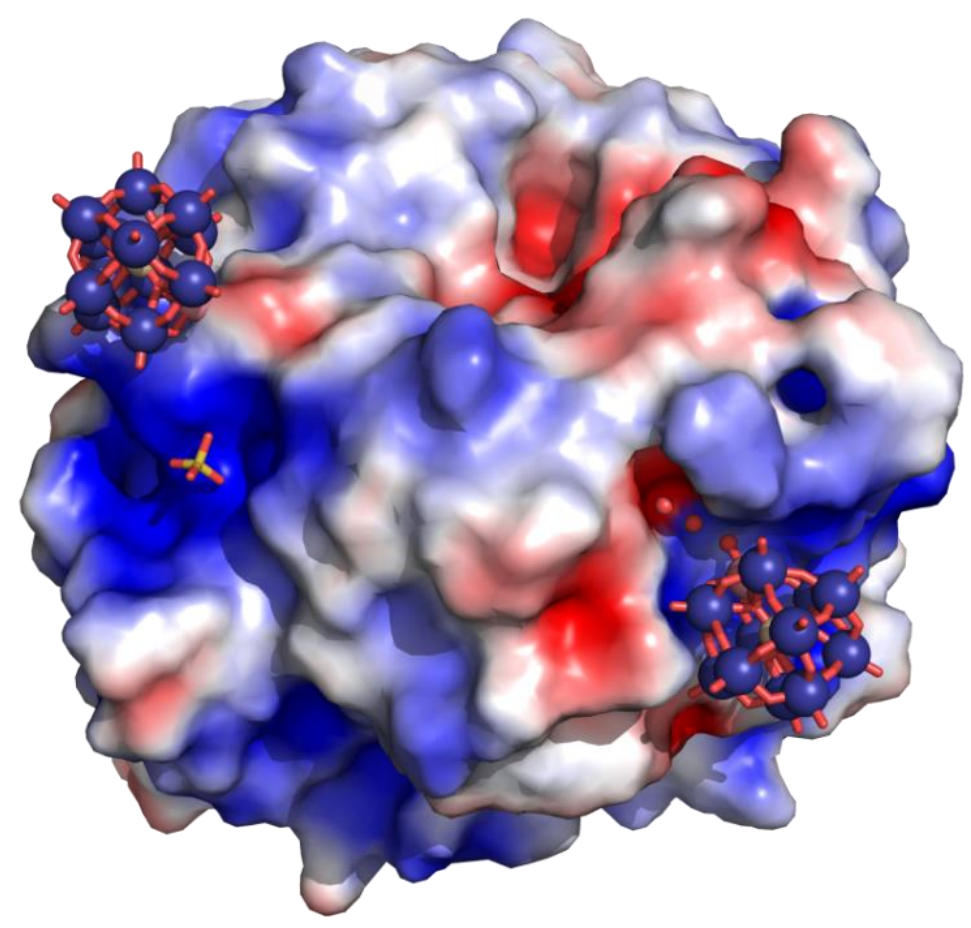

Figure S17. Electrostatic surface representation of proteinase $\mathrm{K}$. This representative protein structure (PDB entry: 7A9F) shows the two main interaction sites of Keggin POTs (here $\alpha$ $\left.\left[\mathrm{SiW}_{11} \mathrm{O}_{39}\left\{\mathrm{Co}\left(\mathrm{H}_{2} \mathrm{O}\right)\right\}\right]^{6-}\right)$ on the surface of proteinase $\mathrm{K}$, in the same orientation as presented in Figure S15. Positive surface patches are shown in blue, negative patches in red and patches with no preferred polarity in white. The polarity range is shown in the color bar (in units of $\mathrm{k}_{\mathrm{B}} \mathrm{T} / \mathrm{e}$ ). The POT, water and sulphate ligands are depicted as ball-and-stick structures with dark blue for $\mathrm{W}$, red for $\mathrm{O}$, ivory for $\mathrm{Si}$, rose for $\mathrm{Co}$ and yellow for $\mathrm{S}$. The POT anions turned out to bind to the same surface cavities as previously observed with similar anions, illustrating a certain binding preference of Keggin POTs with moderate charge density to these sites of mixed polarity. 


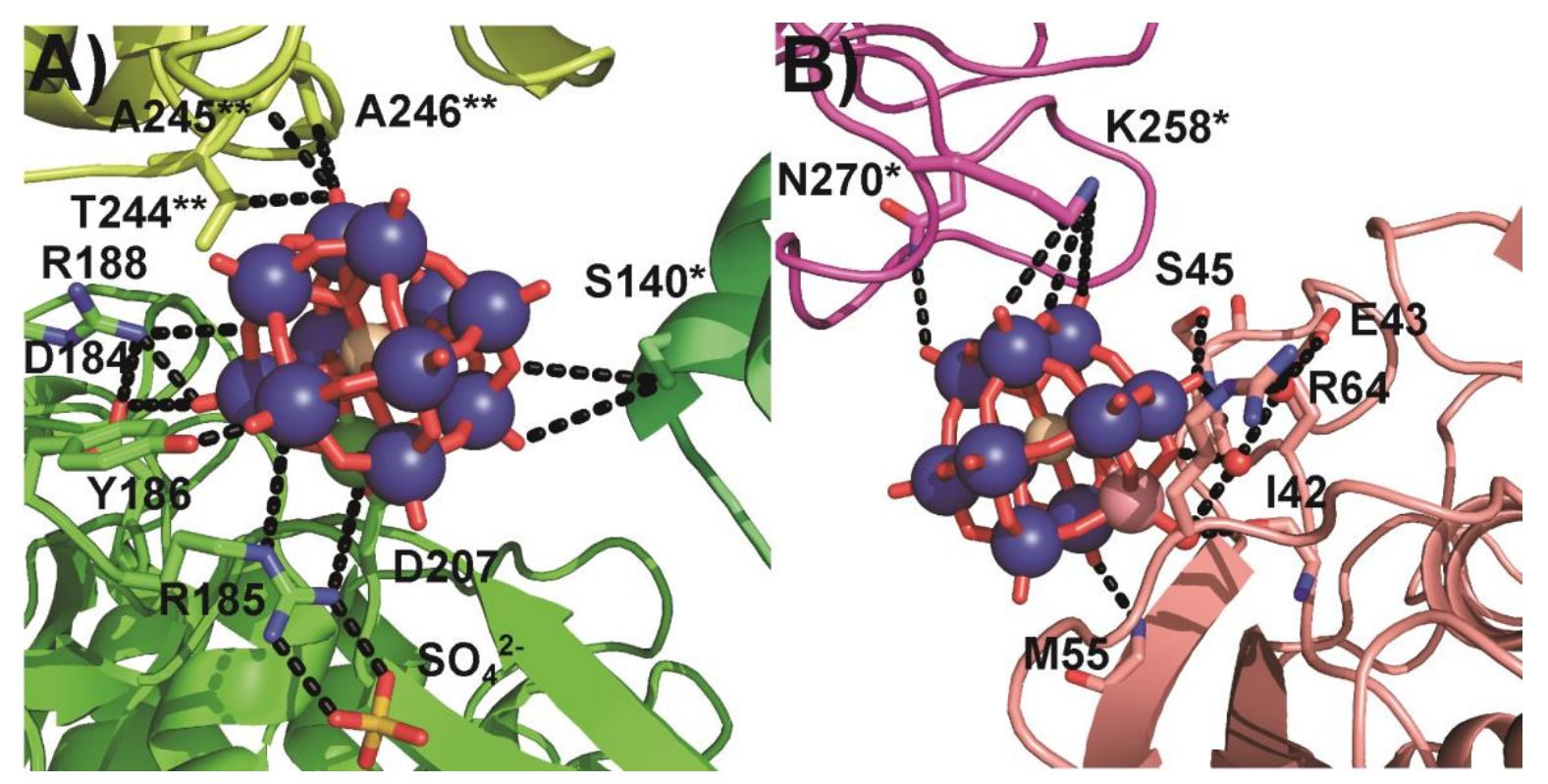

Figure S18. Comprehensive view of Keggin POT interactions with different protein monomers. Distinct protein molecules are represented by different shades of green or red, respectively, and the side chains belonging to the same protein monomer are marked correspondingly with asterisks. One-letter code for amino acids: A, alanine; D, aspartic acid; $\mathrm{E}$, glutamic acid; I, isoleucine; $\mathrm{K}$, lysine; $\mathrm{M}$, methionine; $\mathrm{N}$, asparagine; $\mathrm{R}$, arginine; $\mathrm{S}$, serine; $\mathrm{T}$, threonine; $\mathrm{Y}$, tyrosine. A) Protein interactions around the covalent bond to D207 (position 1). As a representative structure, $\boldsymbol{\alpha}-\left\{\mathrm{SiW}_{11} \mathrm{Ni}\right\}$ (PDB entry: $7 \mathrm{A9K}$ ) was selected. The position of the polyanion is stabilized by main-chain amide and side-chain hydroxyl $\mathrm{H}$ bonding to two more protein chains. B) Protein interactions in the vicinity of the $\mathrm{H}$-bonding network close to $\mathrm{S} 45$ (position 2). As a representative structure, $\boldsymbol{\alpha}$ - $\left\{\mathbf{S i W}_{11} \mathbf{C o}\right\}$ (PDB entry: 7A9F) was selected. A second proteinase $\mathrm{K}$ molecule donates $\mathrm{H}$-bonds to the POT cluster from the opposite side.
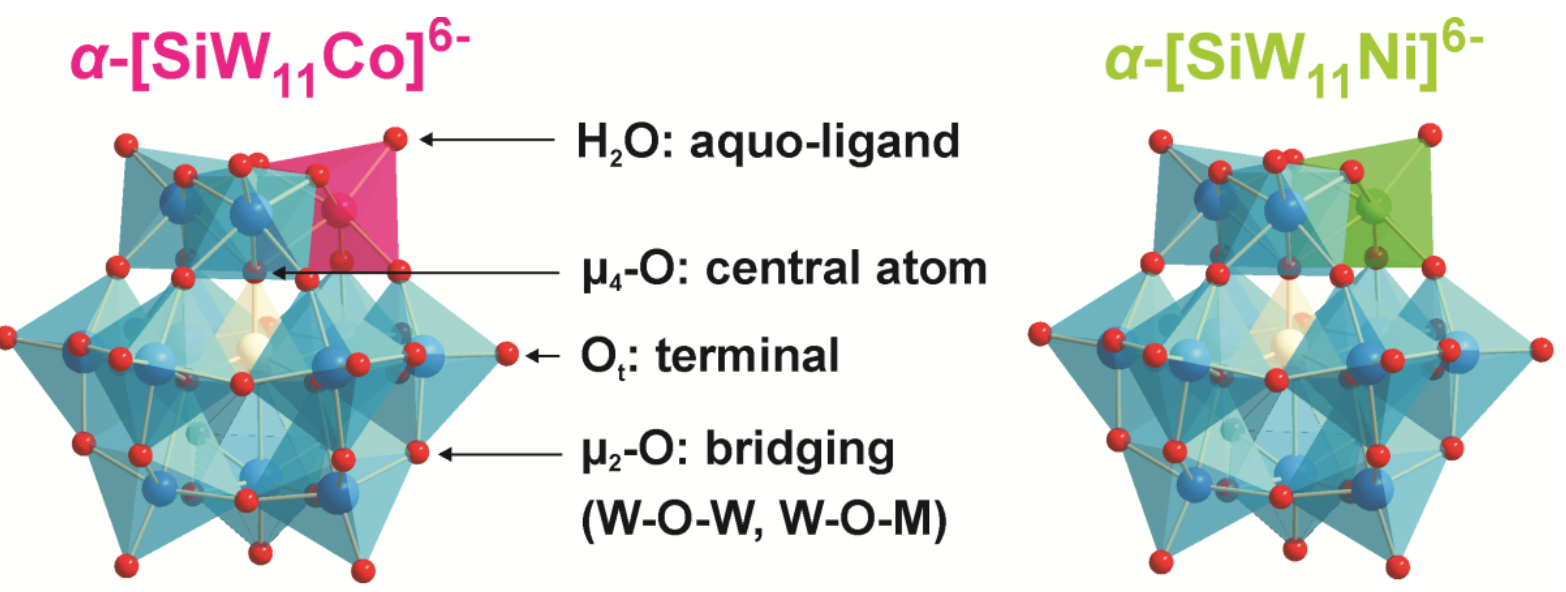

Figure S19. Structures of Keggin POTs as revealed from protein co-crystals and proposed by ESI-MS. The connectivity of the POT architecture is visualized by an overlay of a ball-andstick and a transparent polyhedron model. The central Si (ivory) tetrahedron is enclosed by twelve tungsten atoms, shown as big blue spheres, and surrounded by light blue octahedra, the corners of which are formed by oxygen atoms (red spheres) of various kinds (bridging or terminal). The substituted transition metals (M) are depicted in colors referring to their octahedral complexes (Co": red, $\mathrm{Ni}^{\prime \prime}$ : green), and this color-code is conserved in all following 
figures. As revealed by the protein-POT co-crystal structures presented here later, the Coand $\mathrm{Ni}$-containing POTs featured an aquo-ligand in distorted octahedral geometry.
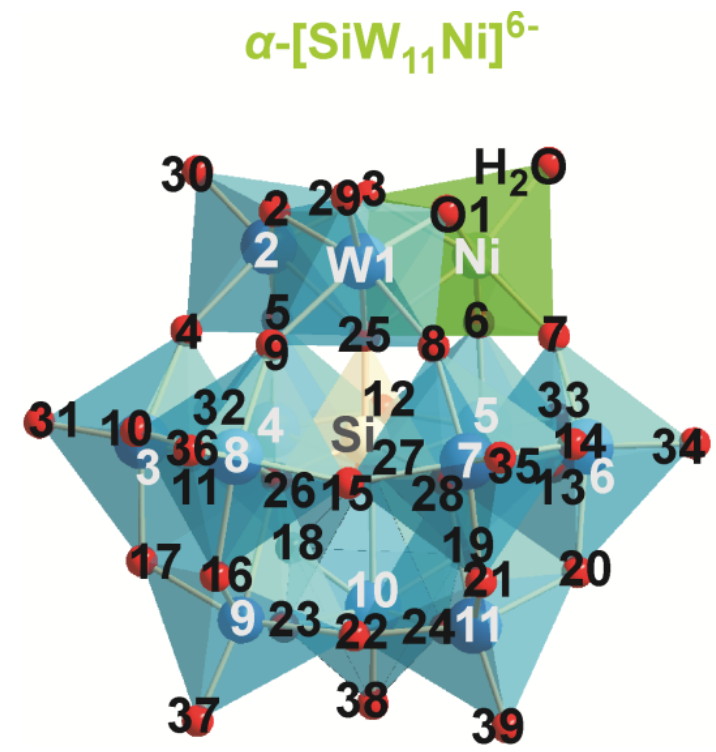

oxygen numbering:

$\mu_{2}-\mathrm{O}$ (bridging)

$\mu_{4}-\mathrm{O}$ (central tetrahedron) $25-28$

$\mathrm{O}_{\mathrm{t}}$ (terminal)

Figure S20. Atom numbering of the representative POT $\boldsymbol{\alpha}-\left\{\mathbf{S i W}_{11} \mathbf{N i}\right\}$. The presented atom numbering provides the basis for the analysis of POT-protein interactions in Tables $\mathbf{S 8}$ and S9. Metal atoms are numbered in light grey and oxygen atoms in black.

Table S7. Charge densities and stability in $\mathrm{H}_{2} \mathrm{O}$ and $\mathrm{NaOAc} / \mathrm{HOAc} \mathrm{pH} 5.5$ based on ESI MS and UV/Vis data of Co- and Ni-substituted Keggin silicotungstates.

\begin{tabular}{|c|c|c|c|c|c|}
\hline POT anion & Abbreviation & $\begin{array}{c}\text { Charge } \\
\text { density } \\
q / m^{\star}\end{array}$ & $\begin{array}{l}\text { Stability } \\
\text { in } \mathrm{H}_{2} \mathrm{O}\end{array}$ & $\begin{array}{c}\text { Stability } \\
\text { in NaOAc } \\
\text { / HOAc pH } \\
5.5\end{array}$ & $\begin{array}{l}\text { Present } \\
\text { in }^{\star \star \star \star \star}\end{array}$ \\
\hline $\begin{array}{c}{[(A-\alpha-} \\
\left.\left.\mathrm{SiW}_{10} \mathrm{O}_{37}\right)_{2}\left\{\mathrm{Co}_{4}(\mathrm{OH})_{2}\left(\mathrm{H}_{2} \mathrm{O}\right)_{2}\right\}\right]^{14-}\end{array}$ & $\left\{\mathrm{SiW}_{10} \mathrm{Co}_{2}\right\}_{2}$ & $\begin{array}{c}14: 24= \\
0.58\end{array}$ & No & No & Solid sate \\
\hline $\begin{array}{c}{[(A-\alpha-} \\
\left.\left.\mathrm{SiW}_{10} \mathrm{O}_{37}\right)_{2}\left\{\mathrm{Ni}_{4}(\mathrm{OH})_{2}\left(\mathrm{H}_{2} \mathrm{O}\right)_{2}\right\}\right]^{14-}\end{array}$ & $\left\{\mathrm{SiW}_{10} \mathrm{Ni}_{2}\right\}_{2}$ & $\begin{array}{c}14: 24= \\
0.58\end{array}$ & No & No & Solid sate \\
\hline $\begin{array}{c}{[A-\alpha-} \\
\left.\mathrm{SiW}_{9} \mathrm{O}_{34}(\mathrm{OH})_{3}\left\{\mathrm{Co}_{4}(\mathrm{OAc})_{3}\right\}\right]^{8-}\end{array}$ & $\left\{\mathrm{SiW}_{9} \mathrm{Co}_{4}\right\}$ & $\begin{array}{c}8: 13= \\
0.61\end{array}$ & n.d. ${ }^{* *}$ & n.d. ${ }^{* *}$ & n.d. ${ }^{* *}$ \\
\hline$\left[\mathrm{SiW}_{10} \mathrm{Co}_{2} \mathrm{O}_{38}\right]^{8-}$ & $\left\{\mathrm{SiW}_{10} \mathrm{Co}_{2}\right\}$ & $\begin{array}{c}8: 12= \\
0.67\end{array}$ & Yes & Yes & $\begin{array}{c}\mathrm{H}_{2} \mathrm{O} \text { and } \\
\mathrm{NaOAc} / \\
\mathrm{HOAc} \mathrm{pH} \\
5.5\end{array}$ \\
\hline$\left[\mathrm{SiW}_{10} \mathrm{Ni}_{2} \mathrm{O}_{38}\right]^{8-}$ & $\left\{\mathrm{SiW}_{10} \mathrm{Ni}_{2}\right\}$ & $\begin{array}{c}8: 12= \\
0.67\end{array}$ & Yes & Yes & $\begin{array}{c}\mathrm{H}_{2} \mathrm{O} \text { and } \\
\mathrm{NaOAc} / \\
\mathrm{HOAc} \mathrm{pH} \\
5.5\end{array}$ \\
\hline$\left[\mathrm{SiW}_{11} \mathrm{CoO}_{39}\right]^{6-}$ & $\left\{\mathrm{SiW}_{11} \mathrm{Co}_{0}\right\}$ & $\begin{array}{c}6: 12= \\
0.5\end{array}$ & n.d. ${ }^{* *}$ & Yes & $\begin{array}{c}\mathrm{NaOAc} / \\
\mathrm{HOAc} \mathrm{pH} \\
5.5\end{array}$ \\
\hline$\left[\mathrm{SiW}_{11} \mathrm{NiO}_{39}\right]^{6-}$ & $\left\{\mathrm{SiW}_{11} \mathrm{Ni}\right\}$ & $\begin{array}{c}6: 12= \\
0.5\end{array}$ & n.d. ${ }^{* * *}$ & Yes & $\begin{array}{c}\mathrm{NaOAc} / \\
\mathrm{HOAc} \mathrm{pH} \\
5.5\end{array}$ \\
\hline
\end{tabular}

${ }^{*} q$ - net charge of POT anion; $\mathrm{m}$ - number of metal centers; ${ }^{* *}$ n.d. - no data available due to the unsuitability for ESI-MS; ${ }^{* * *}$ n.d. - no data available since monosubstituted anions were not detected in pure aqueous solutions; ${ }^{* \star * *}$ valid for this study. 
Table S8. Stabilizing protein interactions in position 1 (Figure 2) for the protein crystal structures with $\alpha-\left\{\right.$ SiW ${ }_{11}$ Co $\}$ (PDB entries: 7 A9F and 7A9M) and $\alpha-\left\{\mathrm{SiW}_{11} \mathrm{Ni}\right\}$ (PDB entry: 7A9K), including hydrogen bonds. The POT atoms are numbered according to Figure S19.

\begin{tabular}{|c|c|c|c|c|c|}
\hline Ligand & Coordinating POT oxygen & Coordinating protein side chain & Distance $[\AA]$ & & \\
\hline & & & $\begin{array}{c}\alpha-\left[\mathrm{SiW}_{11} \mathrm{Co}\right]^{6-} \\
(7 \mathrm{~A} 9 \mathrm{~F})\end{array}$ & $\begin{array}{c}\alpha-\left[\mathrm{SiW}_{11} \mathrm{Ni}\right]^{6-} \\
(7 \mathrm{A9K})\end{array}$ & $\begin{array}{c}\alpha-\left[\mathrm{SiW}_{11} \mathrm{Co}\right]^{6-} \\
(7 \mathrm{~A} 9 \mathrm{M})\end{array}$ \\
\hline POT & aquo-ligand replaced & Asp 207 (Oঠ2, covalent bond), & 1.7 (Оठ2-Co) & $1.3(\mathrm{O} \delta 2-\mathrm{Ni})$ & 1.8 (Оठ2-Co) \\
\hline POT & O $3\left(\mu_{2}\right.$-bridging $)$ & $\operatorname{Arg} 185(\mathrm{~N} \varepsilon)$ & 3.9 & 4.0 & 4.0 \\
\hline POT & O 32 (terminal) & Tyr $186(\mathrm{On})$ & 1.8 & 1.8 & 1.7 \\
\hline POT & O 30 (terminal) & Asp 184 (Oঠ2) & 3.6 & 3.6 & 3.6 \\
\hline POT & O 30 (terminal) & Arg $188(\mathrm{Nn} 2)$ & 3.0 & 2.7 & 2.6 \\
\hline POT & O 4 ( $\mu_{2}$-bridging $)$ & Arg $188(\mathrm{Nn} 2)$ & 3.5 & 3.4 & 3.5 \\
\hline
\end{tabular}

Table S9. Stabilizing protein interactions within the hydrogen-bonding network at position 2 (Figure 3 ) for the protein crystal structures with $\boldsymbol{\alpha}$ $\left\{\right.$ SiW $_{11}$ Co $\}$ (PDB entries: 7A9F and 7A9M) and $\alpha-\left\{S^{2} W_{11}\right.$ Ni $\}$ (PDB entry: 7A9K). The POT atoms are numbered according to Figure S19.

\begin{tabular}{|c|c|c|c|c|c|}
\hline Ligand & $\begin{array}{l}\text { Coordinating POT } \\
\text { oxygen }\end{array}$ & $\begin{array}{c}\text { Coordinating protein side } \\
\text { chain }\end{array}$ & Distance $[\AA]$ & Distance $[\AA]$ & Distance $[\AA]$ \\
\hline & & & $\begin{array}{c}\alpha-\left[\mathrm{SiW}_{11} \mathrm{Co}\right]^{6-} \\
(7 \mathrm{~A} 9 \mathrm{~F})\end{array}$ & $\begin{array}{c}\alpha-\left[\mathrm{SiW}_{11} \mathrm{Ni}\right]^{6-} \\
(7 \mathrm{~A} 9 \mathrm{~K})\end{array}$ & $\begin{array}{c}\alpha-\left[\mathrm{SiW}_{11} \mathrm{Co}\right]^{6-} \\
(7 \mathrm{~A} 9 \mathrm{M})\end{array}$ \\
\hline $\mathrm{POT}+\mathrm{H}_{2} \mathrm{O} 1$ & aquo-ligand & - & 2.1 & 3.3 & 2.1 \\
\hline POT & aquo-ligand & Ile $42(0)$ & 2.7 & 2.6 & 2.6 \\
\hline POT & O 33 (terminal) & Met $55(\mathrm{~N})$ & 2.7 & 2.7 & 2.7 \\
\hline POT & $\mathrm{O} 3\left(\mu_{2}\right.$-bridging $)$ & Ala $44(\mathrm{~N})$ & 3.4 & 3.4 & 3.4 \\
\hline POT & O 30 (terminal) & Ser $45(N)$ & 3.0 & 3.0 & 3.0 \\
\hline POT & O 30 (terminal) & Ser 45 (Oy) & 2.7 & 2.5 & 2.4 \\
\hline $\mathrm{H}_{2} \mathrm{O} 1+\mathrm{H}_{2} \mathrm{O} 2$ & - & - & 3.1 & 3.3 & 3.3 \\
\hline $\mathrm{H}_{2} \mathrm{O} 2+\mathrm{H}_{2} \mathrm{O} 3$ & - & - & 2.9 & 2.8 & 2.7 \\
\hline $\mathrm{H}_{2} \mathrm{O} 3$ & - & Glu 43 (Oع2) & 2.6 & 2.7 & 2.6 \\
\hline $\mathrm{H}_{2} \mathrm{O} 3$ & - & Arg $64(\mathrm{~N} \varepsilon)$ & 4.0 & 4.0 & 4.0 \\
\hline $\mathrm{H}_{2} \mathrm{O} 3$ & - & Arg $64(\mathrm{Nn} 2)$ & 4.9 & 5.1 & 5.1 \\
\hline
\end{tabular}




\section{References}

1 Tézé, A.; Hervé, G.; Finke, R. G. and D. K. Lyon, in Inorganic Syntheses, ed. A. P. Ginsberg, John Wiley \& Sons, Inc., Hoboken, 1990, vol. 27, pp. 85-96.

2 Bruker SAINT V8.32B Copyright (C) 2005-2015 Bruker AXS.

3 Sheldrick, G. M. 1996. SADABS. University of Göttingen, Germany.

4 Sheldrick, G. M. 1996. SHELXS. University of Göttingen, Germany.

5 Sheldrick, G. M. A short history of SHELX. Acta Cryst. 2008, A64, 112-122. DOI: $10.1107 / \mathrm{S} 0108767307043930$

6 Dolomanov, O. V.; Bourhis, L. J.; Gildea, R. J.; Howard, J. A. K.; Puschmann, H. OLEX2: a complete structure solution, refinement and analysis program. J. Appl. Cryst. 2009, 42, 339-341. DOI: 10.1107/S0021889808042726

7 Huebschle, C. B.; Sheldrick, G. M.; Dittrich, B. ShelXle: a Qt graphical user interface for SHELXL. J. Appl. Cryst. 2011, 44, 1281-1284. DOI: $10.1107 / \mathrm{S} 0021889811043202$

8 Tocilj, A.; Schlünzen, F.; Janell, D.; Glühmann, M.; Hansen, H. A. S.; Harms, J.; Bashan, A.; Bartels, H.; Agmon, I.; Franceschi, F.; Yonath, A. Proc. Natl. Acad. Sci. 1999, 96, 14252-14257. DOI: 10.1073/pnas.96.25.14252

9 Rudenko, G.; Henry, L.; Henderson, K.; Ichtchenko, K.; Brown, M. S.; Goldstein, J. L.; Deisenhofer, J. Structure of the LDL Receptor Extracellular Domain at Endosomal $\mathrm{pH}$, Science 2002, 298, 2353-2358. DOI: 10.1126/science.1078124

10 Schemberg, J.; Schneider, K.; Demmer, U.; Warkentin, E.; Müller, A.; Ermler, U. Towards biological supramolecular chemistry: a variety of pocket-templated, individual metal oxide cluster nucleations in the cavity of a Mo/W-storage protein. Angew. Chem., Int. Ed. 2007, 46, 2408- 2413. DOI: 10.1002/anie.200604858 
11 Mauracher, S. G.; Molitor, C.; Al-Oweini, R.; Kortz, U.; Rompel, A. Latent and Active AbPPO4 Mushroom Tyrosinase Cocrystallized with Hexatungstotellurate(VI) in a Single Crystal. Acta Cryst. $D$ 2014, 70, 2301-2315. DOI: $10.1107 /$ S1399004714013777

12 Mauracher, S. G.; Molitor, C.; Al-Oweini, R.; Kortz, U.; Rompel, Crystallization and preliminary X-ray crystallographic analysis of latent isoform PPO4 mushroom (Agaricus bisporus) tyrosinase. Acta Cryst. F 2014, 70, 263-266. DOI: $10.1107 /$ S2053230X14000582

13 Bijelic, A.; Molitor, C.; Mauracher, S. G.; Al-Oweini, R.; Kortz, U.; Rompel, A. Hen Egg-White Lysozyme Crystallisation: Protein Stacking and Structure Stability Enhanced by a Tellurium(VI)-Centred Polyoxotungstate. ChemBioChem 2015, 16, 233-241. DOI: 10.1002/cbic.201402597

14 Molitor, C.; Mauracher, S. G.; Rompel, A. Crystallization and Preliminary Crystallographic Analysis of Latent, Active and Recombinantly Expressed Aurone Synthase, a Polyphenol Oxidase, from Coreopsis grandiflora. Acta Cryst. F 2015, 71, 746-751. DOI: 10.1107/S2053230X15007542

15 Molitor, C.; Mauracher, S. G.; Rompel, A. Aurone Synthase Is a Catechol Oxidase with Hydroxylase Activity and Provides Insights into the Mechanism of Plant Polyphenol Oxidases. Proc. Natl. Acad. Sci. 2016, 113, E1806-E1815. DOI: 10.1073/pnas. 1523575113

16 Molitor, C.; Bijelic, A.; Rompel, A. In Situ Formation of the First Proteinogenically Functionalized $\left[\mathrm{TeW}_{6} \mathrm{O}_{24} \mathrm{O}_{2}(\mathrm{Glu})\right]^{7-}$ Structure Reveals Unprecedented Chemical and Geometrical Features of the Anderson-Type Cluster. Chem. Commun. 2016, 52, 12286-12289. DOI: 10.1039/C6CC07004C

17 Sap, A.; De Zitter, E.; Van Meervelt, L.; Parac-Vogt, T. N. Structural Characterization of the Complex between Hen Egg-White Lysozyme and $\mathrm{Zr}^{\prime \mathrm{l}}$ - 
Substituted Keggin Polyoxometalate as Artificial Protease. Chem. Eur. J. 2015, 21, 11692-11695. DOI: 10.1002/chem.201501998

18 Vandebroek, L.; De Zitter, E.; Ly, H. G. T.; Conić, D.; Mihaylov, T.; Sap, A.; Proost, P.; Pierloot, K.; Van Meervelt, L.; Parac-Vogt, T. N. Protein-Assisted Formation and Stabilization of Catalytically Active Polyoxometalate Species. Chem. Eur. J. 2018, 24, 10099-10108. DOI: 10.1002/chem.201802052

19 Breibeck, J.; Bijelic, A.; Rompel, A. Transition Metal-Substituted Keggin Polyoxotungstates Enabling Covalent Attachment to Proteinase $\mathrm{K}$ upon CoCrystallization. Chem. Commun. 2019, 55, 11519-11522. DOI: $10.1039 /$ C9CC05818D

20 Lisnard, L.; Mialane, P.; Dolbecq, A.; Marrot, J.; Clemente-Juan, J. M.; Coronado, E.; Keita, B.; de Oliveira, P.; Nadjo, L.; Sécheresse, F. Effect of cyanato, azido, carboxylato, and carbonato ligands on the formation of cobalt(II) polyoxometalates: characterization, magnetic, and electrochemical studies of multinuclear cobalt clusters. Chem. Eur. J. 2007, 13, 3525-3536. DOI: 10.1002/chem.200601252

21 Thouvenot, R.; Fournier, M.; Franck, R.; Rocchiccioli-Deltcheff, C. Vibrational investigations of polyoxometalates. 3 . Isomerism in Molybdenum( $\mathrm{VI})$ and Tungsten(VI) compounds related to the Keggin structure. Inorg. Chem. 1984, 23, 598-605. DOI: 10.1021/ic00144a006

22 Haider, A.; Bassil, B. S.; Lin, Z.; Ma, X.; Haferl, P. J.; Bindra, J. K.; Kinyon, J.; Zhang, G.; Keita, B.; Dalal, N. S.; Kortz, U. Synthesis, structure, electrochemistry and magnetism of cobalt-, nickel- and zinc-containing $\left[\mathrm{M}_{4}(\mathrm{OH})_{3}\left(\mathrm{H}_{2} \mathrm{O}\right)_{2}\left(\alpha-\mathrm{SiW}_{10} \mathrm{O}_{36.5}\right)_{2}\right]^{13-}$ $\left(\mathrm{M}=\mathrm{Co}^{2+}, \mathrm{Ni}^{2+}\right.$, and $\left.\mathrm{Zn}^{2+}\right)$. Dalton Trans. 2021, 50, 3923-3930. DOI: 10.1039/DODT03392H

23 Antosiewicz, J. M.; Shugar, D. UV-Vis Spectroscopy of Tyrosine Side-Groups in Studies of Protein Structure. Part 2: Selected Applications. Biophys. Rev. 2016, 8, 163-177. DOI: 10.1007/s12551-016-0197-7 
24 Kabsch, W. XDS. Acta Cryst D. 2010, 66, 125-132. DOI: $10.1107 / S 0907444909047337$

25 McCoy, A. J.; Grosse-Kunstleve, R. W.; Adams, P. D.; Winn, M. D.; Storoni, L. C.; Read, R. J. Phaser crystallographic software. J. Appl. Cryst. 2007, 40, 658-674. DOI: $10.1107 /$ S0021889807021206

26 Adams, P. D.; Afonine, P. V.; Bunkóczi, G.; Chen, V. B.; Davis, I. W.; Echols, N.; Headd, J. J.; Hung, L.-W.; Kapral, G. J.; Grosse-Kunstleve, R. W.; McCoy, A. J.; Moriarty, N. W.; Oeffner, R.; Read, R. J.; Richardson, D. C.; Richardson, J. S.; Terwilliger, T. C.; Zwart, P. H. PHENIX: A comprehensive python-based system for macromolecular structure solution. Acta Cryst. D 2010, 66, 213-221. DOI: $10.1107 /$ S0907444909052925

27 Emsley, P.; Cowtan, K. Coot: Model-building tools for molecular graphics. Acta Cryst. D 2004, 60, 2126-2132. DOI: 10.1107/S0907444904019158 